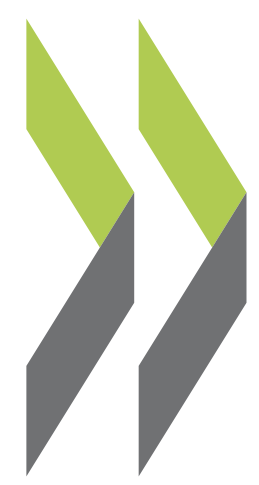

OECD Economics Department Working Papers No. 1468

\title{
Tax reform to support growth and employment in Finland
}

Christophe André, Hyunjeong Hwang 
Organisation de Coopération et de Développement Économiques

Organisation for Economic Co-operation and Development

24-May-2018

ECONOMICS DEPARTMENT

English - Or. English

\section{TAX REFORM TO SUPPORT GROWTH AND EMPLOYMENT IN FINLAND}

ECONOMICS DEPARTMENT WORKING PAPERS No. 1468

By Christophe André and Hyunjeong Hwang

OECD Working Papers should not be reported as representing the official views of the OECD or of its member countries. The opinion expressed and arguments employed are those of the author(s).

Authorised for publication by Álvaro Pereira, Acting Chief Economist, Economics Department.

All Economics Department Working Papers are available at www.oecd.org/eco/workingpapers

JT03432375

This document, as well as any data and map included herein, are without prejudice to the status of or sovereignty over any territory, to the delimitation of international frontiers and boundaries and to the name of any territory, city or area. 
OECD Working Papers should not be reported as representing the official views of the OECD or of its member countries. The opinions expressed and arguments employed are those of the author(s).

Working Papers describe preliminary results or research in progress by the author(s) and are published to stimulate discussion on a broad range of issues on which the OECD works.

Comments on Working Papers are welcomed, and may be sent to the Economics Department, OECD, 2 rue André-Pascal, 75775 Paris Cedex 16, France, or by e-mail to eco.contact@oecd.org.

All Economics Department Working Papers are available at www.oecd.org/eco/workingpapers.

This document and any map included herein are without prejudice to the status of or sovereignty over any territory, to the delimitation of international frontiers and boundaries and to the name of any territory, city or area.

The statistical data for Israel are supplied by and under the responsibility of the relevant Israeli authorities. The use of such data by the OECD is without prejudice to the status of the Golan Heights, East Jerusalem and Israeli settlements in the West Bank under the terms of international law.

\section{(c) OECD (2018)}

You can copy, download or print OECD content for your own use, and you can include excerpts from OECD publications, databases and multimedia products in your own documents, presentations, blogs, websites and teaching materials, provided that suitable acknowledgment of OECD as source and copyright owner is given. All requests for commercial use and translation rights should be submitted to rights@oecd.org 


\section{ABSTRACT/RÉSUMÉ}

\section{Tax reform to support growth and employment in Finland}

Finland raises a large amount of taxes to finance high-quality public services and redistribute income. Public finances are currently relatively solid and taxes and transfers reduce income inequality significantly. However, a rapidly ageing population pushes up public spending, while globalisation creates challenges in raising revenue. Hence, ensuring long-term fiscal sustainability requires both containing spending through efficiency gains in the provision of public services and raising revenue in a way that minimises deadweight costs and distortions weighing on growth and employment. Reducing further the tax wedge on labour income would lift employment. More revenue could be raised through a reduction in the range of goods and services subject to reduced VAT rates, higher taxes on consumption that is harmful to the environment or health and higher property taxes. A competitive corporate taxation, combined with international cooperation to avoid base erosion and profit shifting, is needed to foster local production.

This Working Paper relates to the 2018 OECD Economic Survey of Finland (www.oecd.org/eco/surveys/economic-survey-finland.htm).

Keywords: Finland, taxation, subsidies, corporate income tax, personal income tax, tax evasion, environmental taxation.

JEL classification codes: H23; H24; H25; H26

$$
* * * * * * * * * * * * *
$$

\section{Réformer la fiscalité pour soutenir la croissance et l'emploi en Finlande}

La Finlande lève un montant d'impôts élevé pour financer des services publics de qualité et redistribuer les revenus. Les finances publiques sont actuellement relativement solides et les impôts et transferts réduisent considérablement les inégalités de revenus. Toutefois, le vieillissement rapide de la population augmente les dépenses publiques, tandis que la mondialisation complique la collecte de recettes. Par conséquent, pour assurer la viabilité budgétaire à long terme, il est nécessaire à la fois de contenir les dépenses grâce à des gains d'efficacité dans la fourniture de services publics et d'augmenter les recettes en minimisant les poids morts et les distorsions pesant sur la croissance et l'emploi. Réduire davantage le coin fiscal sur le revenu du travail stimulerait l'emploi. Des recettes supplémentaires pourraient être dégagées grâce à une réduction de la gamme des biens et services assujettis à des taux de TVA réduits, à des taxes plus élevées sur les consommations nuisibles à l'environnement ou à la santé, et à des impôts fonciers plus élevés. Une fiscalité des entreprises compétitive, associée à une coopération internationale pour éviter l'érosion de la base imposable et le transfert des bénéfices, est nécessaire pour favoriser la production locale.

Ce Document de travail se rapporte à l'Étude économique du Finlande 2018 (www.oecd.org/fr/eco/etudes/etude-economique-finlande.htm).

Mots-clés: Finlande, fiscalité, subventions, impôt sur les sociétés, impôt sur le revenu des personnes physiques, évasion fiscale, fiscalité environnementale.

JEL classification codes: H23; H24; H25; H26 


\section{TABLE OF CONTENTS}

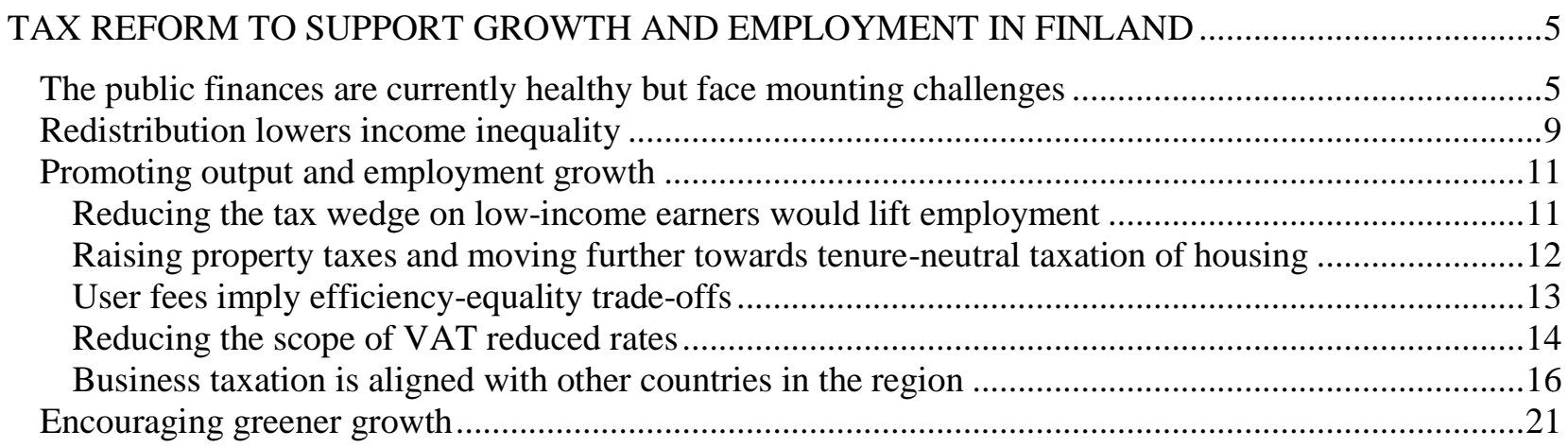

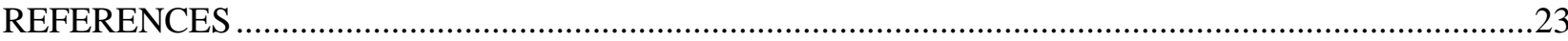

\section{Tables}

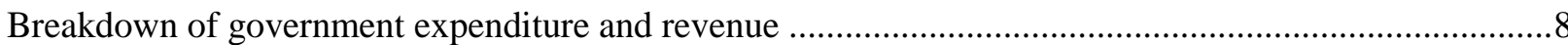

Figures

The tax burden is among the highest in the oecd 6

Social spending is not as high in international comparison when private social spending and taxation of

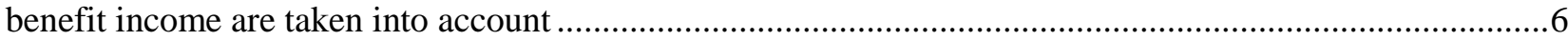

The government deficit is modest but debt has risen markedly ..................................................................

Government revenue has failed to keep up with spending over the past decade..........................................

Government gross debt remains relatively low and assets are large .........................................................

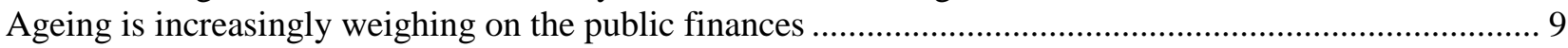

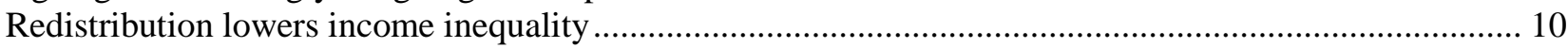

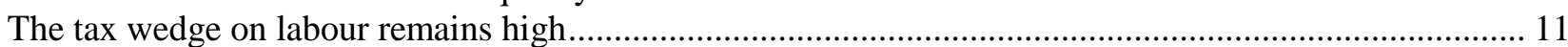

The combined top marginal rate of personal income tax and employee social security contributions is high

.

Tax revenue from recurrent taxes on immovable property is still relatively low .......................................13

The earnings premium from tertiary education is higher than in the other nordics...................................14

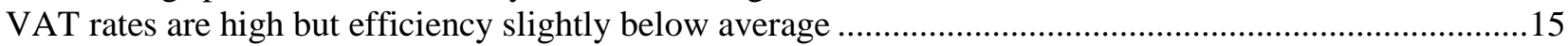

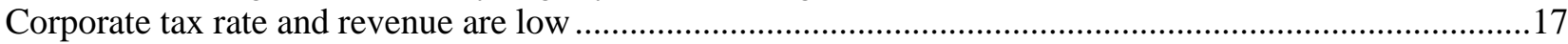

Corporate tax revenue has so far held up relatively well despite sharp tax rate cuts ..................................18

Environmentally related tax revenue is high compared to other oecd countries .......................................22

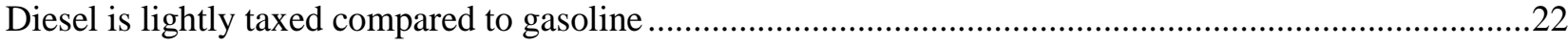

\section{Boxes}

Box 1. Tackling tax avoidance: The OECD/G20 BEPS project 
ECO/WKP(2018)16

\title{
TAX REFORM TO SUPPORT GROWTH AND EMPLOYMENT IN FINLAND
}

\author{
By Christophe André and Hyunjeong Hwang ${ }^{1}$
}

Until the global financial crisis, the Finnish economic model has successfully fostered inclusive growth. Economic efficiency, innovation and strong integration in the global economy are combined with a solid social safety net which dampens income inequality and preserves social cohesion. However, the past decade has been challenging, due to the global economic slump, difficulties in the electronic and paper industries, a deep recession in Russia and rising ageing-related costs. The government budget balance has moved from a healthy surplus to a moderate deficit and gross government debt now exceeds $60 \%$ of GDP. Hence, government spending needs to be contained and more revenue raised in an efficient way to preserve the sustainability of public finances, while continuing to provide high-quality public services. Moreover, robust public finances are important to leave space for fiscal stimulus in the event of a large adverse economic shock, like the global financial and economic crisis of 2008. A number of measures to strengthen the fiscal position have already been taken. A pension reform entered into force in 2017, a health care and social services reform is under preparation, with implementation due in 2020, and more immediate savings measures have been taken. Moreover, the tax mix has become more growth-friendly over recent years, with an increasing share of revenue from indirect, property and environmentally-related taxes. The government has committed not to raise the total tax rate and to reduce labour taxes (Prime Minister's Office, 2015).

Nevertheless, as the population ages and globalisation increases the mobility of tax bases, funding the welfare state in a fair and efficient way is becoming more challenging. The government estimated the public finance sustainability gap, i.e. the structural excess of spending over revenue, at about EUR 8 billion or around 3\% of GDP in September 2017 (Ministry of Finance, 2017a). The 2015 government programme set out to close the sustainability gap, then estimated at EUR 10 billion, through EUR 4 billion of shortterm savings, EUR 1 billion in long-term public sector cost reductions, EUR 3 billion of efficiency gains due to the health care and social services reform, and EUR 2 billion additional revenue generated by employment and growth measures. While short-term savings are being achieved, the outcome of the other policies is still uncertain. In addition to raising the efficiency of public spending, ensuring that the tax and benefit system supports growth, competitiveness and employment is crucial to ensure long-term fiscal sustainability, while providing high-quality public services and preserving the ability of the welfare state to contain income inequality.

\section{The public finances are currently healthy but face mounting challenges}

Government revenue as a share of GDP is among the highest in the OECD and comparable to that of the other Nordic countries (Figure 1). This reflects high tax rates on broad tax bases. Across OECD countries, higher government spending tends to be correlated with lower long-term growth. However, the correlation does not hold for countries with well-functioning governments. This is particularly the case for the Nordic countries, where government effectiveness is at its highest (Fournier and Johansson, 2016). The large government size reflects extensive income redistribution, the provision of a wide range of public services, as well as high public social spending (Figure 2, Panel A). As the distribution of tasks between the public and private sector varies widely across countries and benefits in Finland are taxed, which is not

\footnotetext{
${ }^{1}$ OECD Economics Department. The authors would like to thank Bert Brys, Luisa Dressler, Tibor Hanappi, Pierce O'Reilly and Kurt Van Dender from the OECD Centre for Tax Policy and Administration, Peter Hoeller, Åsa Johansson, Vincent Koen, Patrick Lenain, Jon Kristian Pareliussen and Alvaro Pereira from the OECD Economics Department, Willem Adema, Michael Förster, Horacio Levy and Angelica Salvi Del Pero from the OECD Directorate for Employment, Labour and Social Affairs, as well as members of the Finnish administration and the OECD Economic Development Review Committee, for valuable comments and suggestions; also thanks to Sisse Nielsen and Mercedes Burgos for excellent editing support.
} 
Figure 1. The tax burden is among the highest in the OECD

Taxes and social security contributions, 2016 or latest

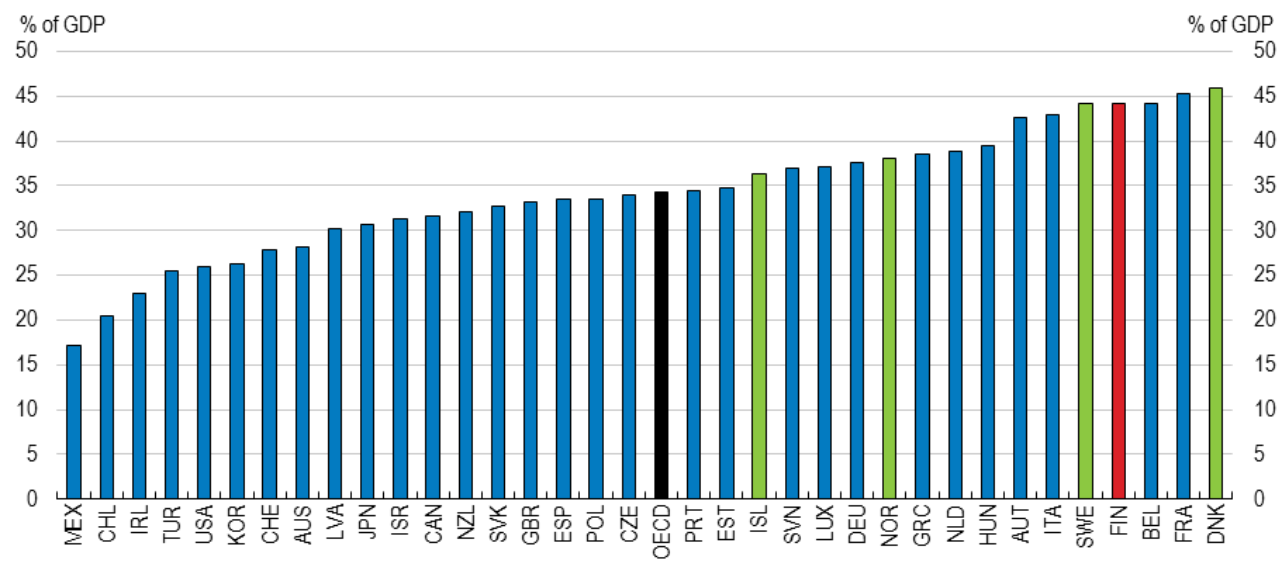

Source: OECD Revenue Statistics database.

always the case in other countries, a more accurate assessment of welfare spending is given by total net social spending, which includes both public social expenditure and private social spending (e.g. private pensions or health care insurance benefits) and takes taxation of benefits into account (Adema et al., 2011). Finnish net social spending is considerably lower than gross spending, even though it is still above the OECD average (Figure 2, Panel B).

Figure 2. Social spending is not as high in international comparison when private social spending and taxation of benefit income are taken into account

A. Public social spending, 2016 or latest

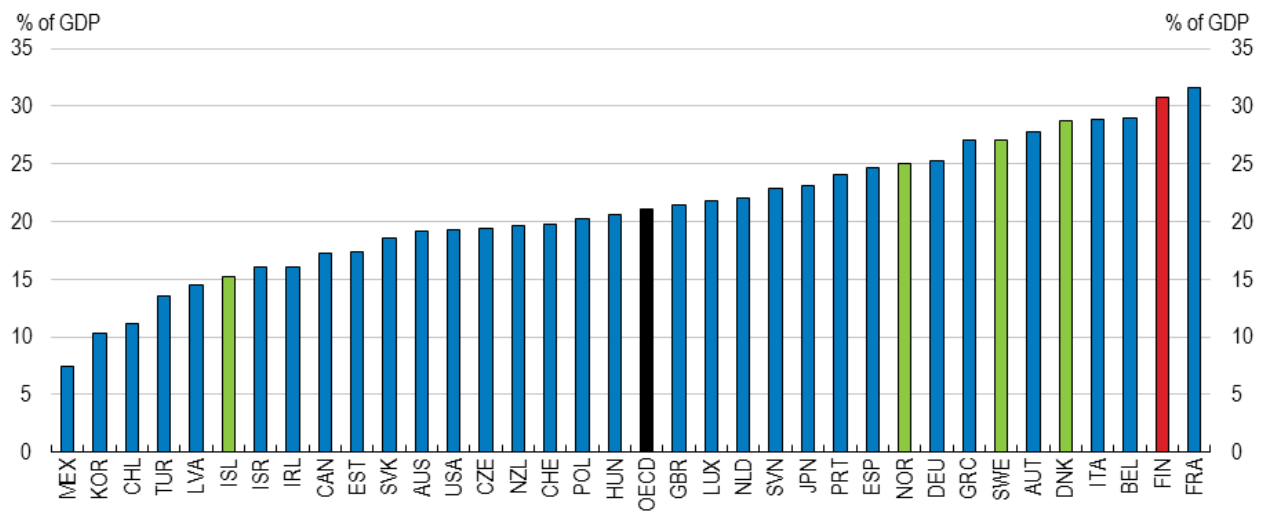

B. Total net social spending, 2013 or latest

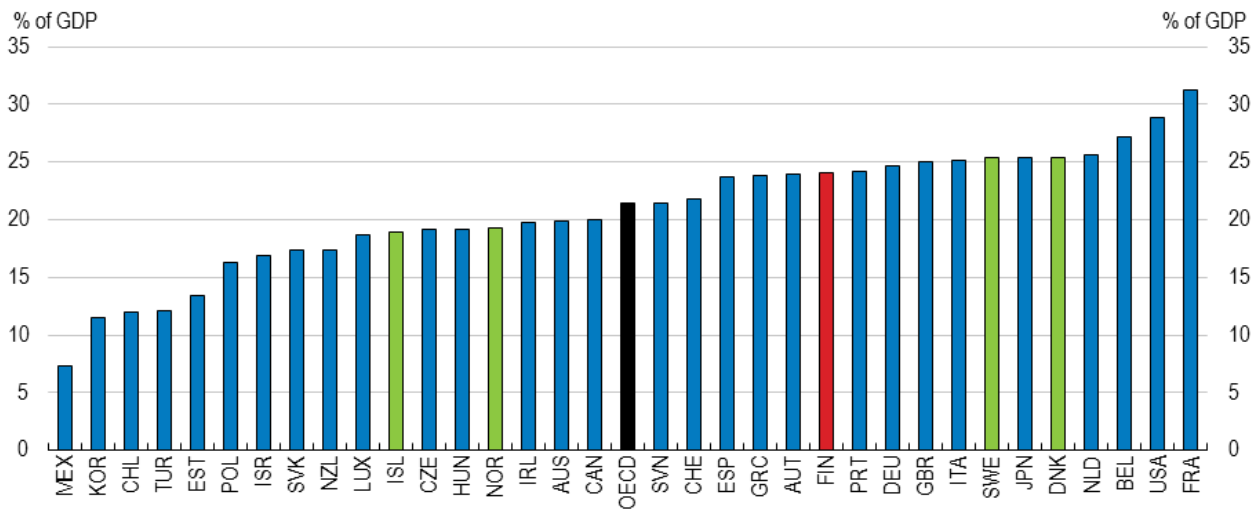

Source: OECD Social Expenditure database. 
Since 2009, the general government budget has shown small deficits, driving general government debt (Maastricht definition) over 60\% of GDP (Figure 3). Some taxes, including the standard VAT rate and some excise duties have been increased. Nevertheless, with a stagnating economy, increases in revenue have failed to match spending growth, even though the recent pick-up in growth has generated higher revenue and spending has been contained since 2015 (Figure 4). Expenditure growth has been driven by social benefits, which were pushed up by population ageing and higher unemployment (Table 1.1). The level of gross government debt remains relatively modest by OECD standards and the government has a positive net asset position thanks to partial pre-funding of pensions (Figure 5). However, population ageing is starting to weigh heavily on the public finances, even though ongoing and planned reforms will help. The pension reform put in place in early 2017 will gradually raise the lower pension age limit from 63 to 65 years and link it to longevity thereafter, which is expected to strengthen the government balance by approximately $1 \%$ of GDP once the reform is fully implemented (Finnish Economic Policy Council, 2015). Even so, pension spending will rise significantly until 2030 (Figure 6). So will health and long-term care expenditures, even though their increase could be dampened by the health care and social services reform to be implemented in 2020 .

Figure 3. The government deficit is modest but debt has risen markedly

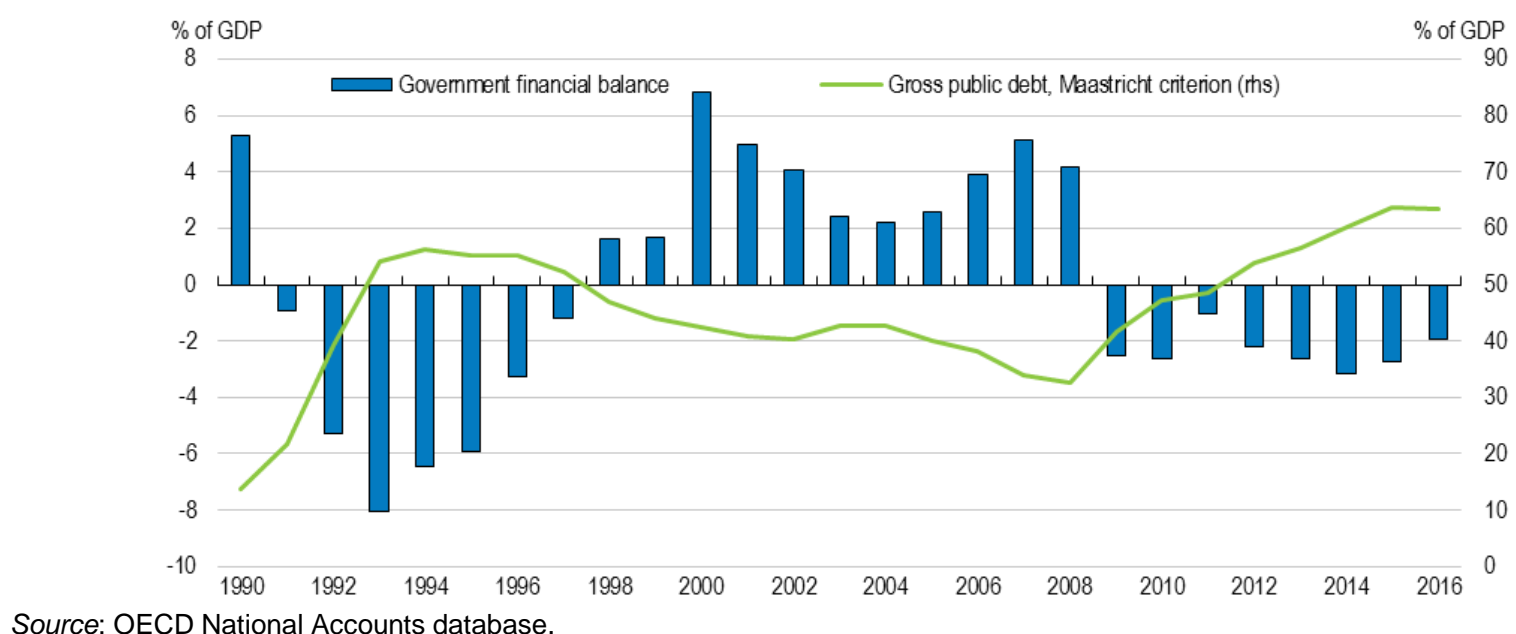

Figure 4. Government revenue has failed to keep up with spending over the past decade

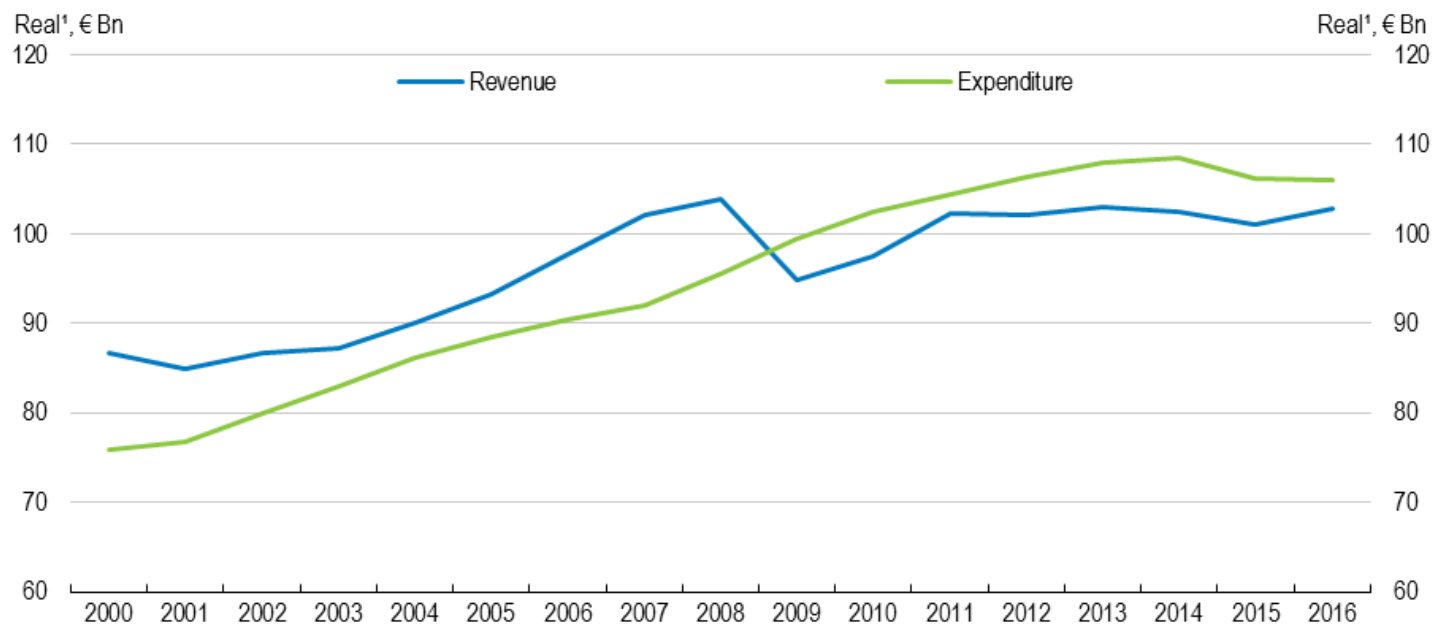

1. Deflated by GDP deflator $(2010=1)$.

Source: OECD National Accounts database. 
Figure 5. Government gross debt remains relatively low and assets are large

A. Gross government debt, Maastricht definition (2016 or latest)

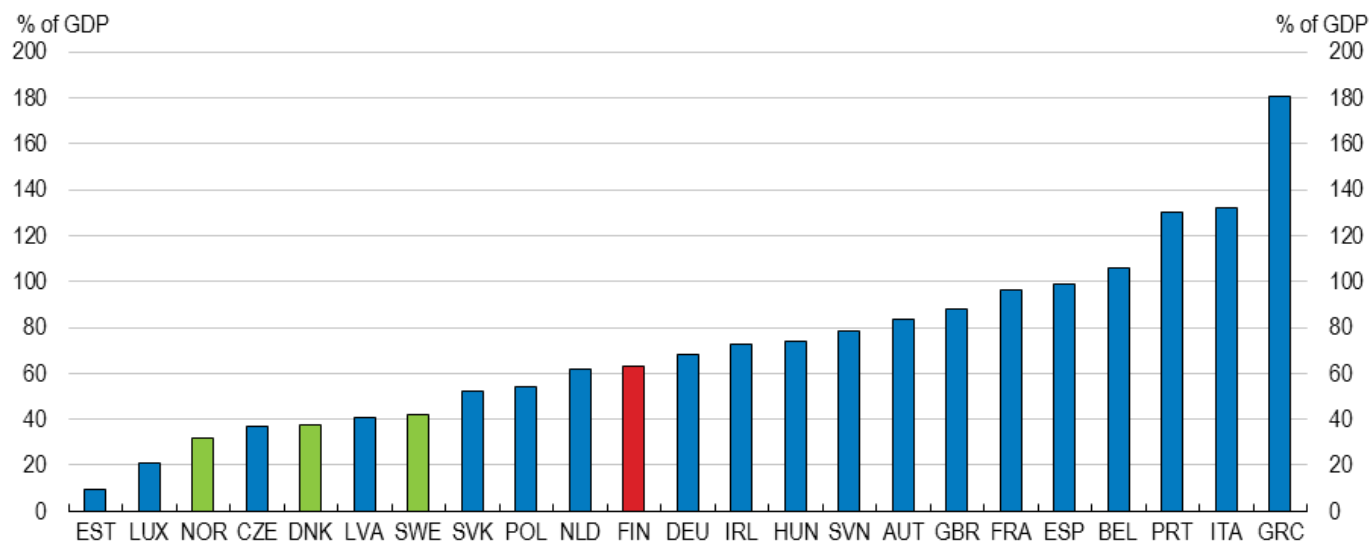

B. Net government debt, National Accounts definition (2016 or latest)

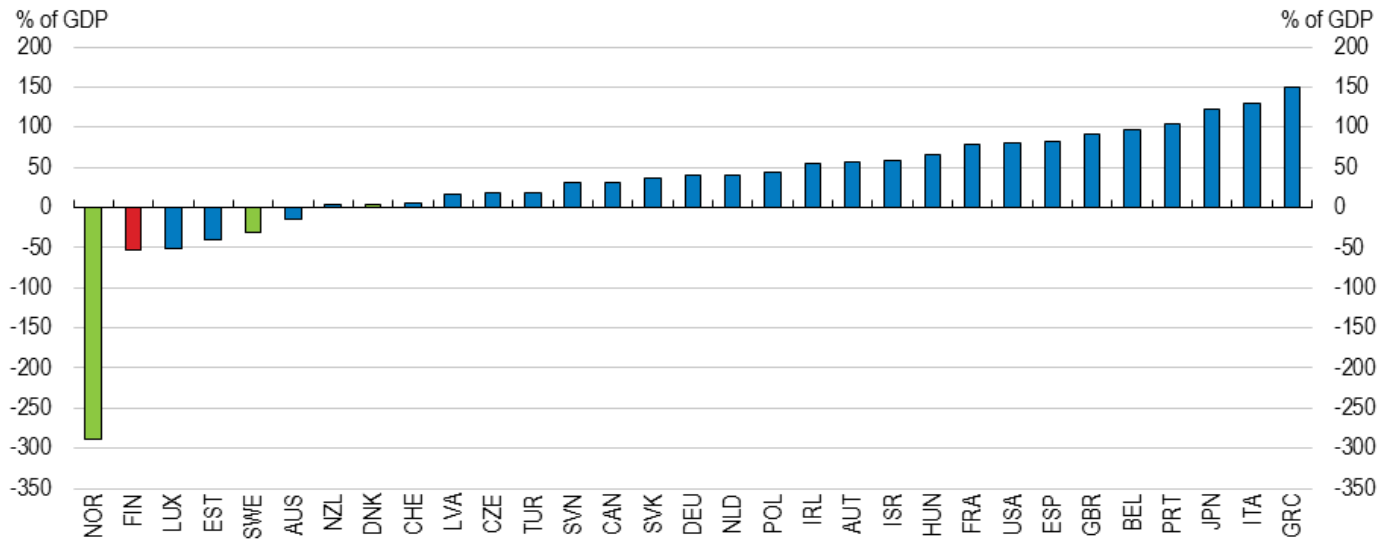

Source: OECD National Accounts database.

Table 1. Breakdown of government expenditure and revenue Per cent of GDP

\begin{tabular}{|c|c|c|c|c|c|c|}
\hline \multirow[b]{3}{*}{ Total expenditure } & \multicolumn{3}{|c|}{ Level } & \multicolumn{3}{|c|}{ Change } \\
\hline & 2001 & 2008 & 2016 & 2001-16 & 2001-08 & 2008-16 \\
\hline & 47.3 & 48.3 & 56.1 & 8.8 & 1.0 & 7.8 \\
\hline \multicolumn{7}{|l|}{ Of which: } \\
\hline Consumption & 20.0 & 21.7 & 24.2 & 4.2 & 1.7 & 2.5 \\
\hline Of which: wages & 12.6 & 12.9 & 13.5 & 0.9 & 0.3 & 0.6 \\
\hline Social benefits & 15.3 & 14.7 & 19.8 & 4.5 & -0.6 & 5.1 \\
\hline Total receipts & 52.3 & 52.4 & 54.2 & 1.9 & 0.1 & 1.8 \\
\hline \multicolumn{7}{|l|}{$\begin{array}{l}\text { Of which: } \\
\text { Direct taxes }\end{array}$} \\
\hline \multicolumn{7}{|l|}{ Direct taxes } \\
\hline Households & 14.1 & 13.2 & 14.0 & -0.1 & -0.9 & 0.8 \\
\hline Corporations & 4.3 & 3.6 & 2.6 & -1.7 & -0.7 & -1.0 \\
\hline Indirect taxes & 12.9 & 12.4 & 14.4 & 1.5 & -0.5 & 2.0 \\
\hline Social contributions & 11.8 & 11.6 & 13.1 & 1.3 & -0.2 & 1.5 \\
\hline
\end{tabular}

Source: OECD, Economic Outlook database. 
Figure 6. Ageing is increasingly weighing on the public finances
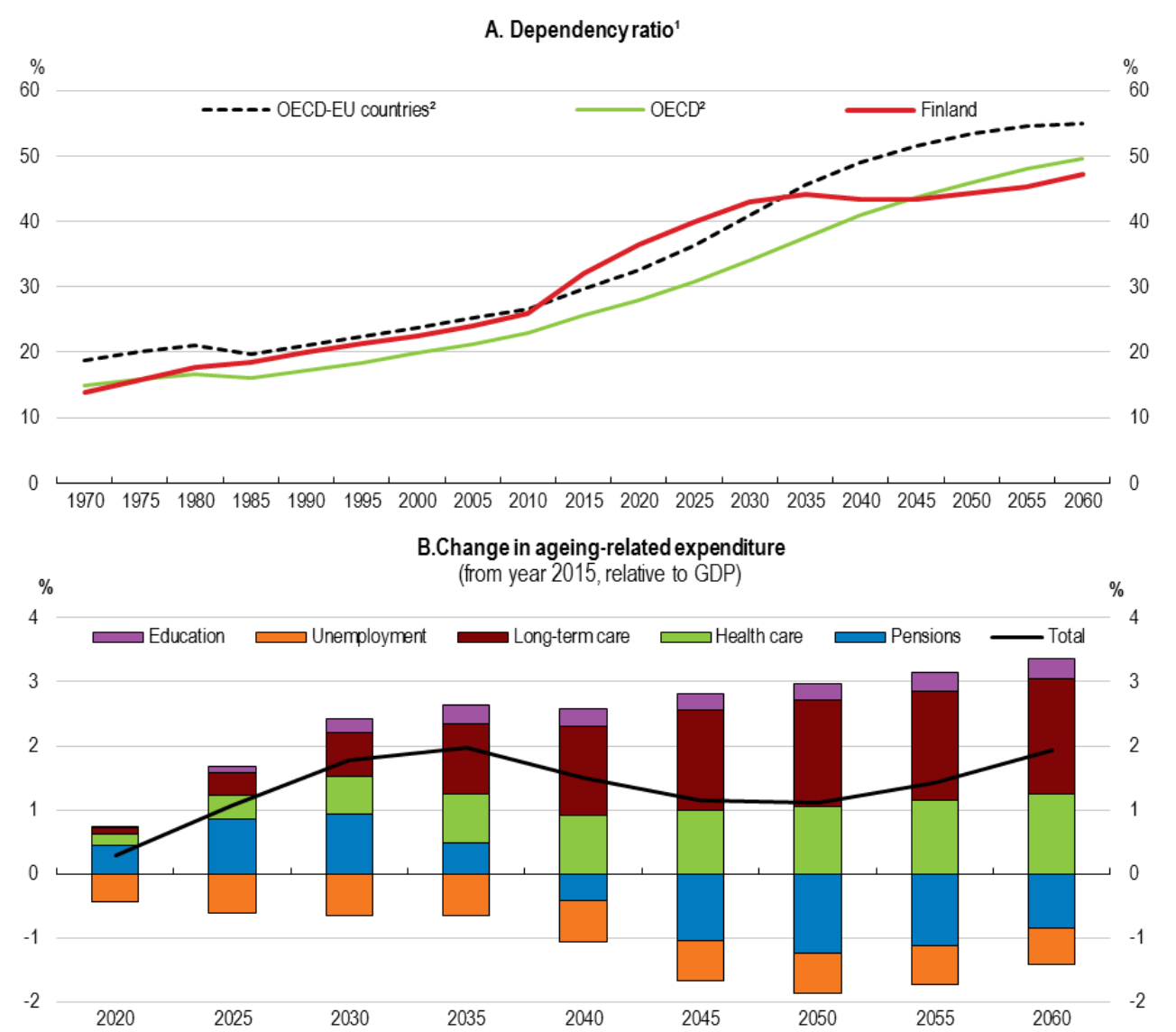

1. Ratio of population aged 65 and over per 100 people aged $15-64$.

2. Weighted average.

Source: United Nations Population Division, World Population Prospects: The 2017 Revision; OECD calculations; and Finnish Ministry of Finance.

The government expects the health care and social services reform to boost the annual growth of productivity in health care and social services by around 1.5 percentage points in the 2020s and to reduce the sustainability gap by 1.3 percentage points of 2017 GDP (Ministry of Finance, 2017a). However, such estimates are very uncertain. In addition, the declining share of the working age population, as well as weak productivity developments, lowers potential output and hence the possibility to raise fiscal resources. Indeed, Finland is among the few OECD countries where fiscal space has shrunk since 2014, as the fall in real interest rates on public debt has been more than offset by the reduction in potential output (Botev et al., 2016).

\section{Redistribution lowers income inequality}

The Gini coefficient of market income increased rapidly in the early 1990s, mainly because of a sharp fall in employment as the economy went through a deep recession. Meanwhile, redistribution kept the Gini coefficient of disposable income (i.e. after tax and transfers) broadly stable. However, later in the decade, inequality in disposable income increased significantly, albeit from a very low level (Figure 7, Panel A). Redistribution through benefits has declined, largely because of falling unemployment, even though benefit cuts also played a role. The 1993 introduction of the dual income tax system, which lowered capital income taxation considerably for high-income households also increased inequality (Riihelä et al., 2002 and 2008; Moisio et al., 2016). Cuts in labour taxes between 1998 and 2008 increased the concentration of income and wealth only modestly, while raising employment somewhat (Lehmus, 2014). Since the early 2000s, the Gini coefficient of disposable income has been relatively stable and it remains among the lowest in the OECD (Panel B). The contribution of the tax and benefit system to reducing income inequality is one of the strongest in the OECD (Panel C). Taxes and benefits also contribute to reducing relative poverty (Panel D). 
Figure 7. Redistribution lowers income inequality

\section{A. Gini coefficient}

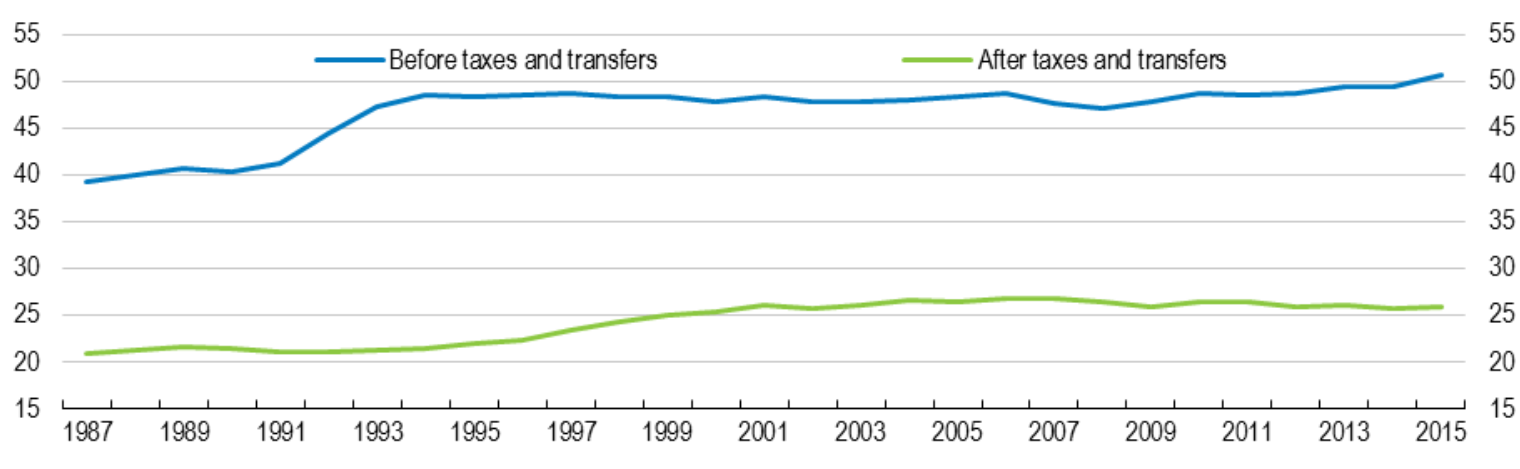

B. Gini coefficient after taxes and transfers (2015or latest)

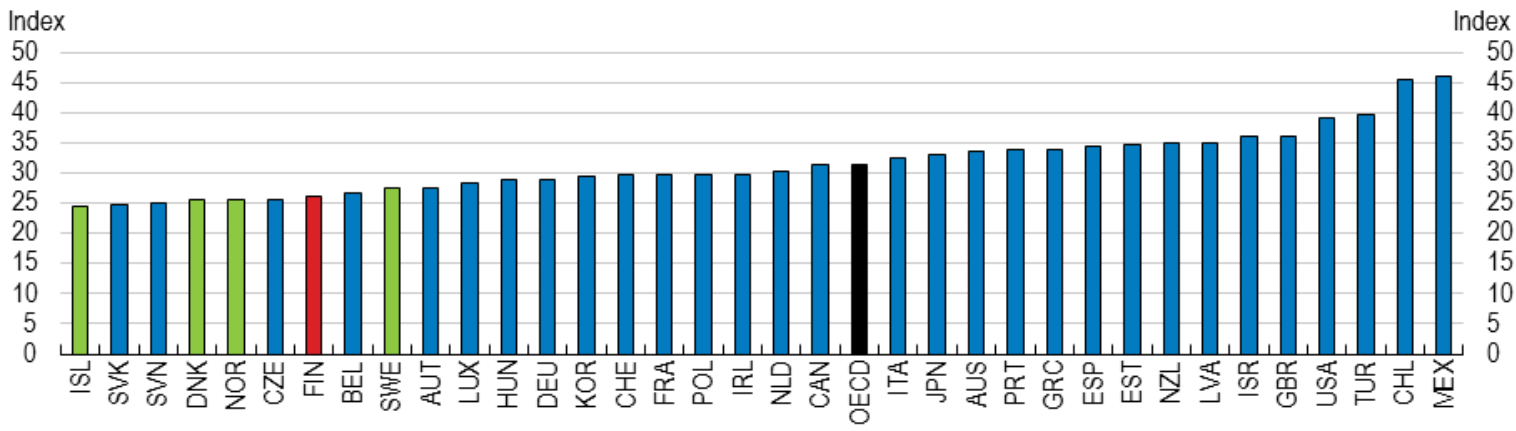

\section{Redistribution through taxes and transfers ( 2015 or latest $)^{1}$}

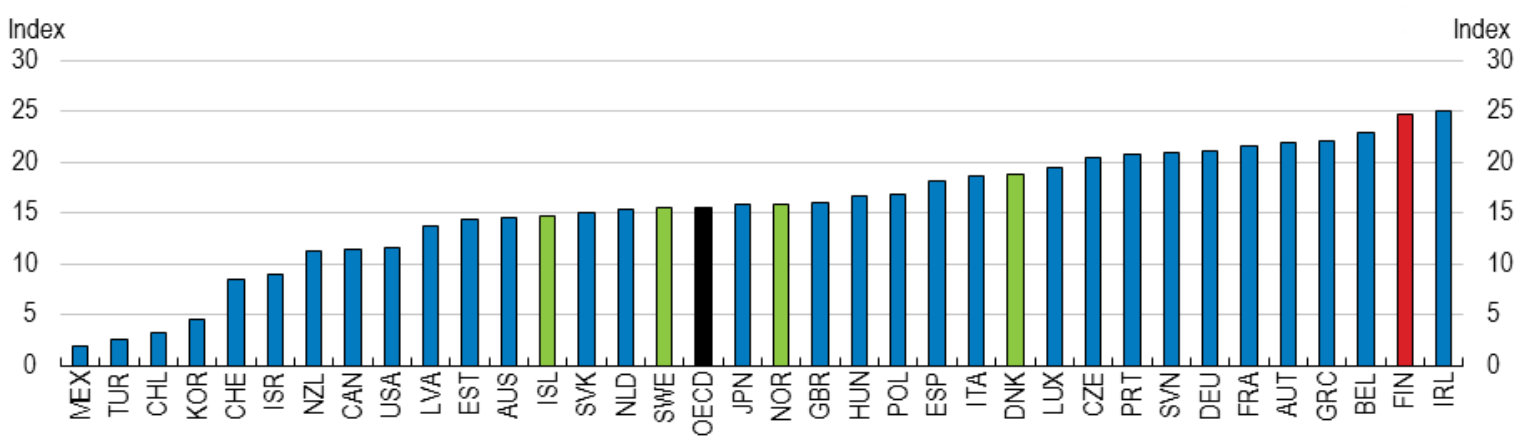

\section{Poverty rate ${ }^{2}$}

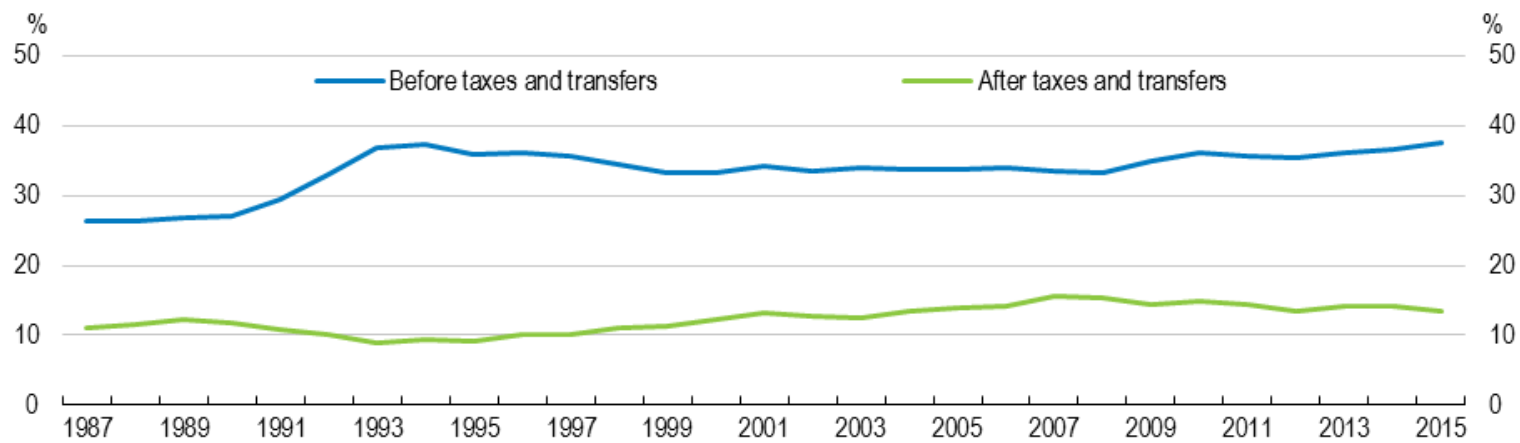

1. The difference between the Gini coefficients for market income and disposable income.

2. The poverty rate is the percentage of households whose income falls below the poverty line, taken as $60 \%$ of the median household income of the total population.

Source: OECD Income Distribution Database (IDD). 


\section{Promoting output and employment growth}

\section{Reducing the tax wedge on low-income earners would lift employment}

The tax wedge on labour was among the highest in the OECD in 2016, even though the tax wedge may be underestimated in some countries, where some mandatory social contributions are not taken into account (Figure 8). Tax and social contribution cuts related to the Competitiveness Pact signed by the social partners in 2016 reduce this wedge somewhat from 2017 onwards. Substantial increases in the maximum amount of the earned income tax credit in 2016 and 2017 enhance work incentives (OECD, 2017a). Nevertheless, reducing the tax wedge further would push up labour supply and demand, thereby contributing to lift the employment rate, which is the lowest among the Nordic countries. The tax wedge can be reduced through lowering taxes on labour and offsetting the revenue loss by higher indirect taxes and recurrent taxes on personal immovable property. Pareliussen and Hwang (2018) provides a more detailed analysis of the marginal effective tax rates different population groups are facing when modifying their labour supply and assesses the impact of the tax and benefit system on work incentives.

\section{Figure 8. The tax wedge on labour remains high}

2016

A. Single, no children, $67 \%$ average wage

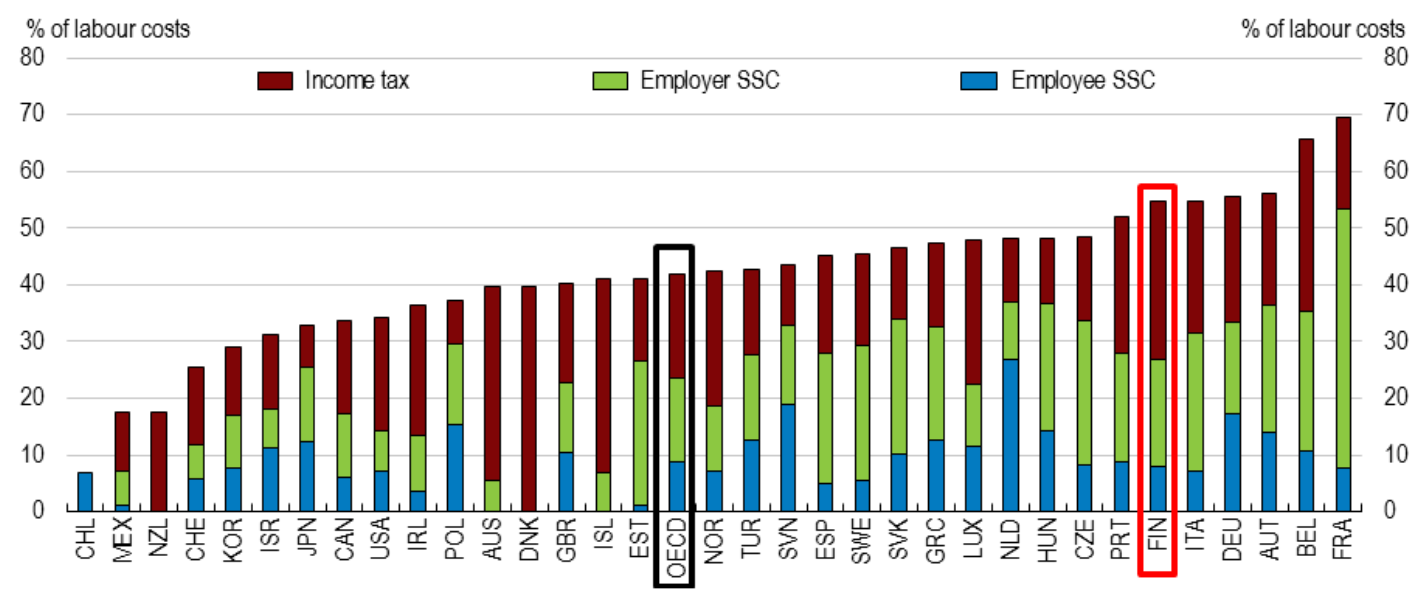

B. One-earner married couple, 2 children, $67 \%$ average wage

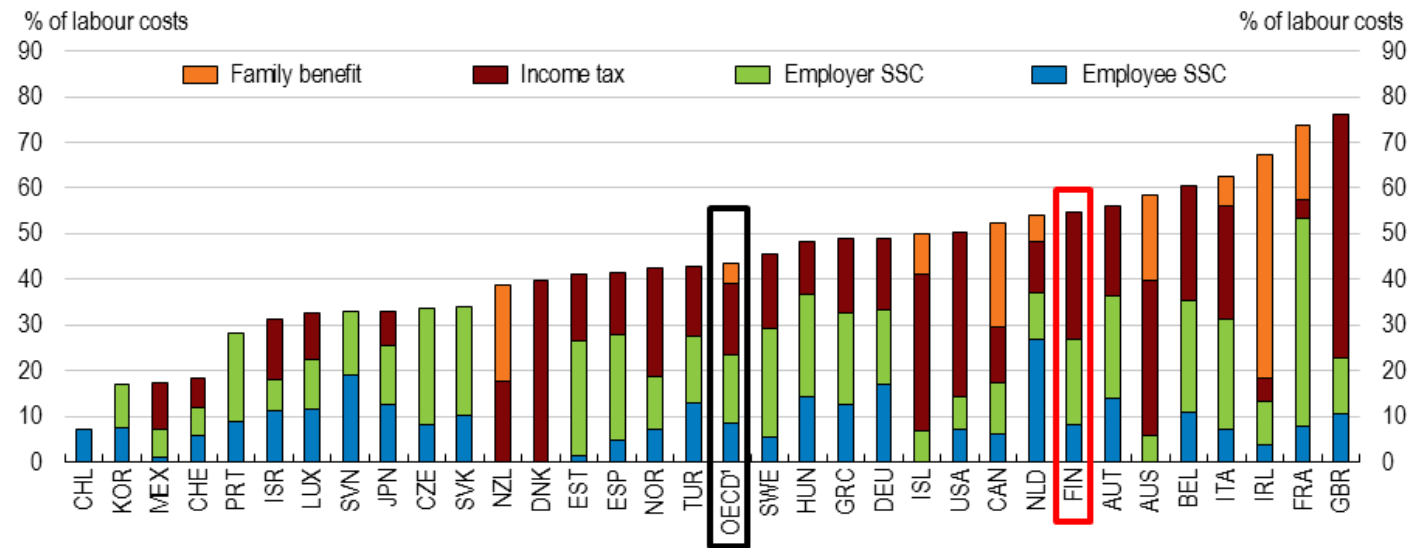

1. OECD average excludes Poland.

Source: OECD Taxation database.

As in the other Nordics, the combined top marginal rate of personal income tax and employee social security contributions is high (Figure 9, Panel A). The top marginal personal tax rate applies at a relatively 
low threshold (Panel B). Moreover, this threshold has been lowered temporarily for the current government's term, through the solidarity tax. To promote entrepreneurship, the government recently introduced a 5\% PIT deduction for entrepreneurs and the self-employed and increased the tax deduction for work-related expenses. However, this may create incentives for employees to become self-employed or to contract their labour to their employers (OECD, 2015b). A potential adverse effect of a high top marginal PIT rate in international comparison is that it may make it difficult to retain or attract highly skilled individuals. However, labour mobility remains limited and most neighbouring countries also apply high PIT top rates. Another mitigating factor is that qualified foreign experts may apply for a special tax status, under which they are taxed at a flat rate of $35 \%$ for 48 months.

\section{Figure 9. The combined top marginal rate of personal income tax and employee social security contributions is high \\ 2016}

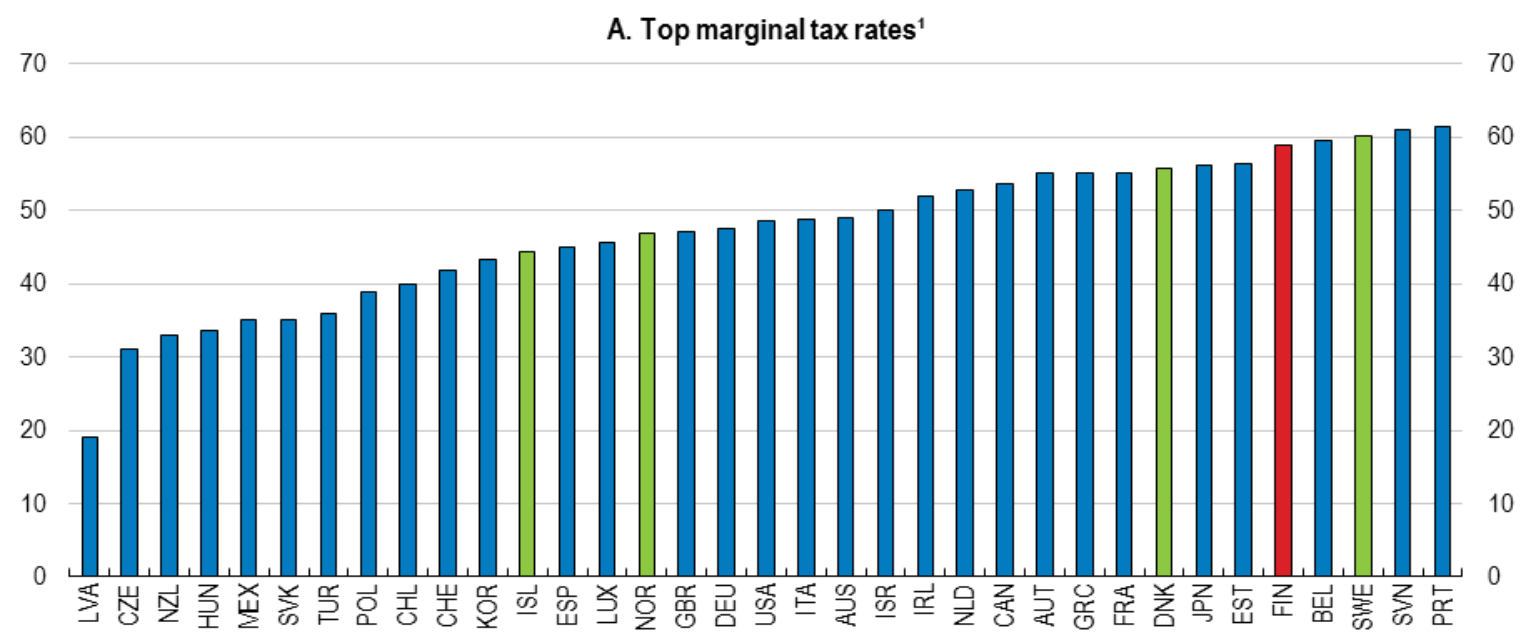

B. Threshold for paying the top marginal tax rate ${ }^{2}$

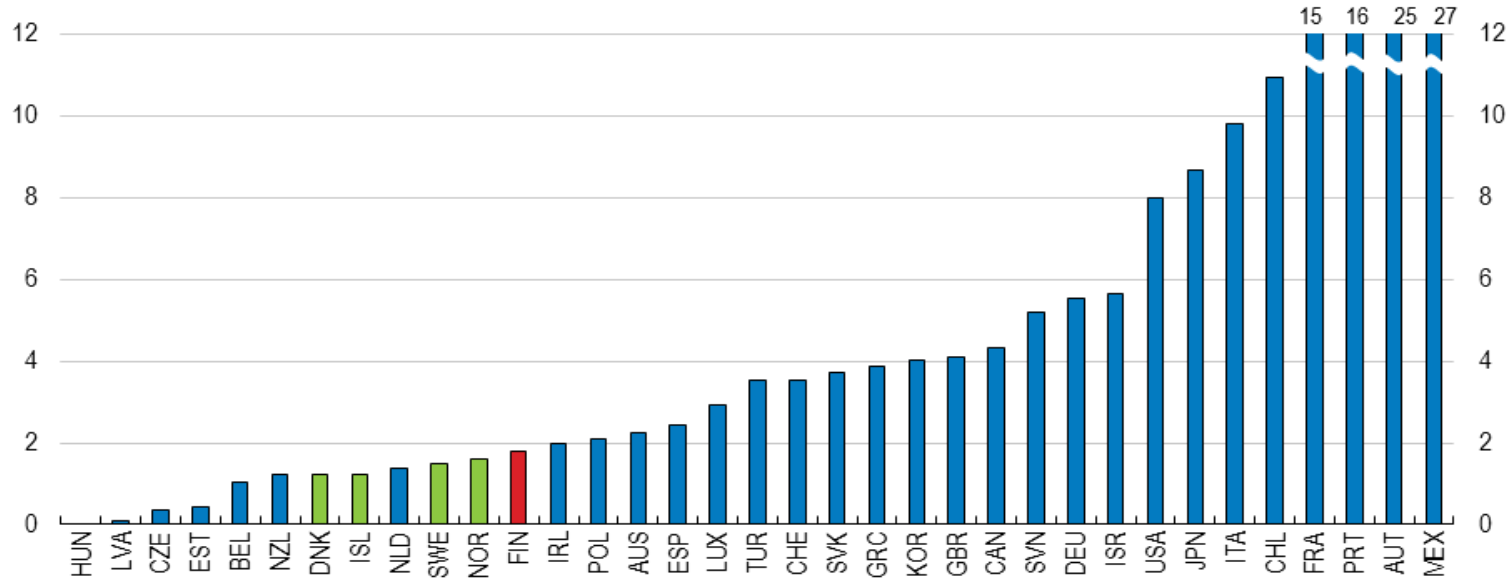

1. Personal income tax and employee social security contributions (all-in rate).

2. Expressed as a multiple of the average wage.

Source: OECD Taxation database.

\section{Raising property taxes and moving further towards tenure-neutral taxation of housing}

Recurrent taxes on immovable property are generally considered as among the least harmful to economic growth (Arnold et al., 2011; Johansson, 2016). Property taxes can also be designed to be progressive, and can reduce distortions in the way households allocate their savings across assets. In 
addition, reducing the tax bias in favour of home-ownership and linking property taxes to regularly updated property valuations could reduce housing price volatility (van den Noord, 2005; Muellbauer, 2006; Blöchliger et al., 2015a). Finland has been moving away from favouring home-ownership towards more tenure-neutral taxation over recent years, through higher property taxes and reduced tax relief on mortgages. In 2014, property assessment values were revised and further updating to bring cadastral values closer to market values is expected to be completed by the early 2020s. The lower and higher thresholds of the range within which municipalities may set their property tax rate have been increased in steps. Mortgage interest deductibility from personal income tax is being gradually reduced, as in a number of other EU countries.

Nevertheless, property tax revenue in Finland remains below the OECD average (Figure 10). Residential property taxes are also regressive, as municipalities with high average incomes tend to set lower tax rates. Hence, there is potential to raise a larger share of local government revenue through property taxation, as well as to make the taxation of property more progressive. For municipalities, higher property taxes can alleviate the effect of cuts in grants from central government. Higher revenue from property taxes also strengthens the incentives for municipalities to zone more land for development and speed up planning processes, enhancing the responsiveness of housing supply to demand. Property taxes are generally unpopular, especially because they are highly visible and sometimes perceived as unfair, as they are disconnected from the ability to pay. In particular, property taxes may put a heavy burden on asset-rich income-poor households. However, these problems can be mitigated by means-tested exemptions for low-income households or measures to alleviate liquidity constraints, such as tax deferral (Blöchliger, 2015b).

Figure 10. Tax revenue from recurrent taxes on immovable property is still relatively low 2016 or latest

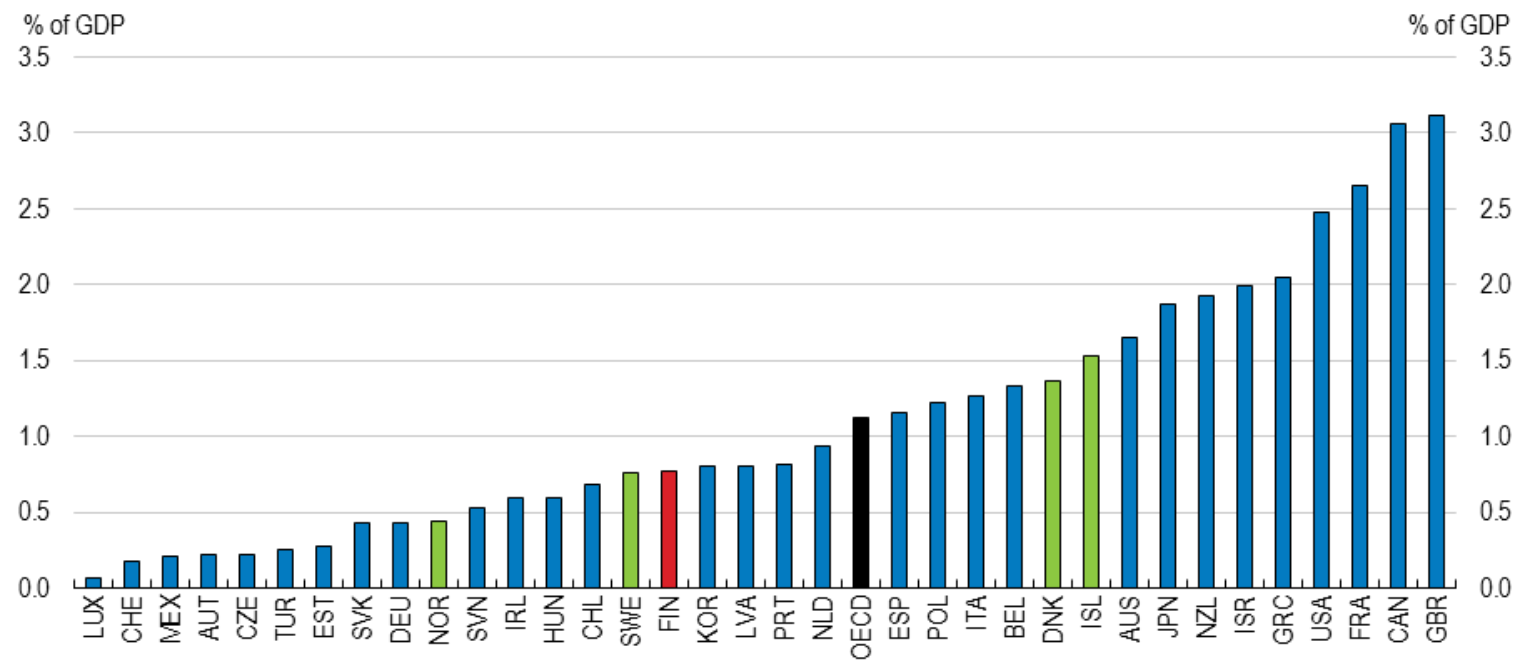

Source: OECD Taxation database.

\section{User fees imply efficiency-equality trade-offs}

Finnish local authorities raise a substantial amount of user fees, representing more than $9 \%$ of general government revenue and about a fourth of local government income. The high share of user fees in OECD comparison partly reflects the wide range of services provided by Finnish municipalities. The largest part of user fees relates to utility charges and public transport, with modest fees charged on public health care, while basic education is free.

Finland, like the other Nordic countries, charges no tuition fees for national students on public tertiary education. Most other OECD countries charge tuition fees, albeit at widely varying rates (OECD, 2016a). 
Tuition fees may be justified by the earnings premium derived from tertiary education; tertiary students will earn far more than these fees on higher education in higher earnings over their lifetimes (OECD, 2017b). In addition, they may enhance the efficiency and quality of education by encouraging timely completion of studies, raising student expectations for value for money and increasing the responsiveness of institutions to student and labour market demand. In the Nordic countries, however, tuition fees tend to face strong opposition, in part because high value is put on financial independence of young adults from their parents (Koutsogeorgopoulou, 2016). The earnings premium for tertiary graduates in Finland is below the OECD average, but somewhat higher than in the other Nordic countries (Figure 11). Completion times are long by OECD standards (OECD Economic Survey of Finland 2016).

Economists from the Research Institute of the Finnish economy have recently suggested that tertiary education establishments should be allowed to charge moderate tuition fees to increase their resources on a permanent basis (Määttänen and Vihriälä, 2017). If such a measure were to be adopted, it would need to be combined with expanded grants to at-risk students, or with a system of income-contingent loans, as in Australia, the Netherlands, New Zealand and the United Kingdom. Such a system can reduce the long-run public cost of higher education and increase funding for higher education institutions, as well as promote access, equity, completion, and positive outcomes for students (OECD, 2012). Careful design, in particular regarding the level of tuition fees, interest rates on loans, repayment thresholds and rates, and write-off periods are crucial to ensure efficiency and fairness (Barr et al., 2017; Belfield et al., 2017; OECD, 2017b).

Figure 11. The earnings premium from tertiary education is higher than in the other Nordics' 2015

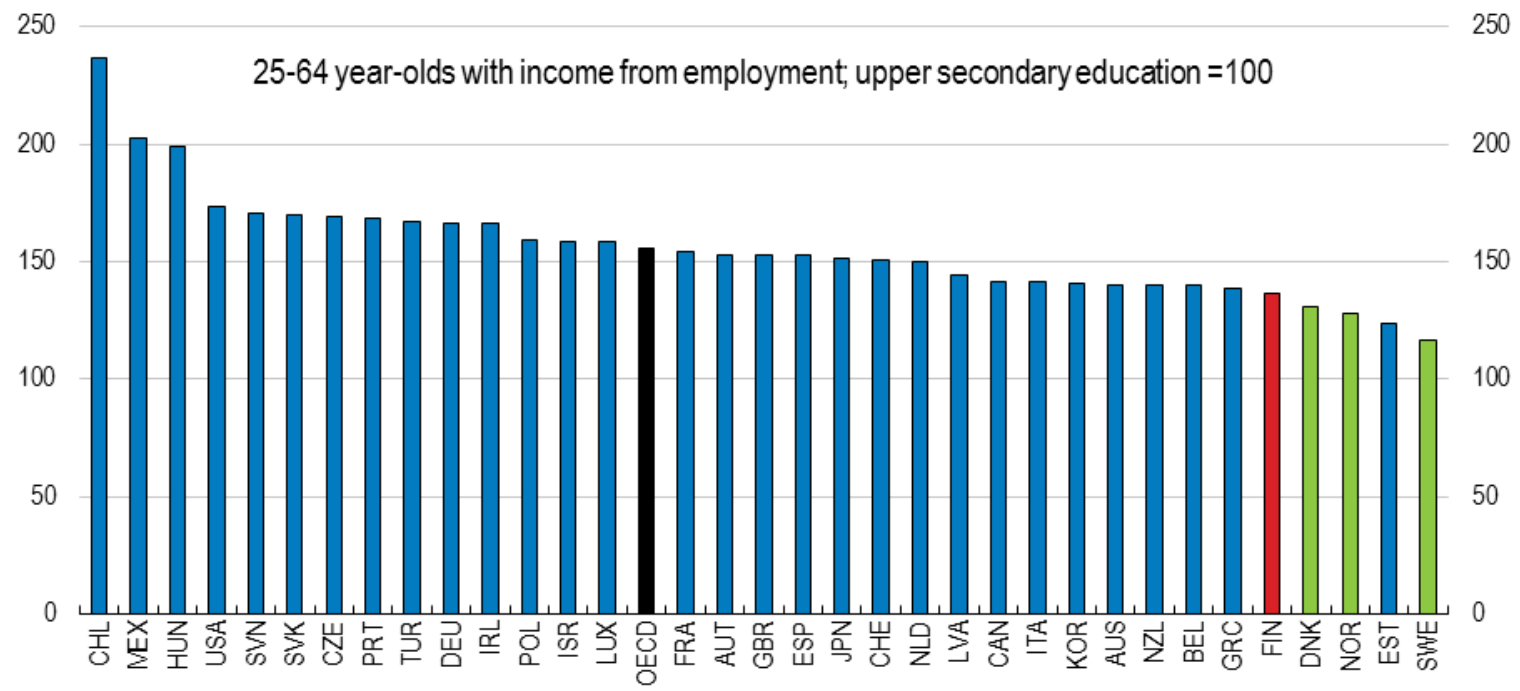

1. Earnings of 25-64 year-old full-time full-year workers who attained tertiary education, relative to those who attained upper secondary education.

Source: OECD (2017), Education at a Glance 2017, Table A6.1.

\section{Reducing the scope of $V A T$ reduced rates}

Finland has a 24\% standard VAT rate, which is among the highest in the OECD (Figure 12, Panel A), but a number of goods and services are taxed at lower rates or exempt. A $14 \%$ rate applies to food and restaurants. A $10 \%$ rate applies to a wide range of items, including books, pharmaceutical products, accommodation, passenger transport services and some sport and cultural activities. VAT-exempt goods and services include health care, social services and education, as well as most financial and insurance services. These exemptions are similar to those applied in most other OECD countries. Nonetheless, they create significant distortions to prices and a bias against outsourcing. The VAT efficiency ratio (i.e. the ratio of actual VAT revenue to potential VAT revenue if all goods and services were taxed at the standard VAT rate) is only about 54\%, slightly below the OECD average (Figure 12, Panel B). A number of 
countries achieve higher efficiency, even though Luxembourg and New Zealand are special cases, reflecting the VAT treatment of financial services and e-commerce in Luxembourg and the fact that public services are subject to VAT in New Zealand (OECD, 2016c).

Finland, like seven other EU countries (including Denmark and Sweden), has a refund system to compensate public entities for not being able to deduct VAT on their inputs, which eliminates distortions in interactions with the private sector. In particular, in the absence of refunds, there is a bias against outsourcing, as external inputs are subject to non-deductible VAT, while internally-produced inputs are not (OECD, 2016c).

The main reason for exempting financial services from VAT is the difficulty in measuring the tax base. However, taxing financial services in a way which would achieve a similar outcome as VAT seems feasible (Mirrlees, 2011). Countries which have pursued this avenue include France and Denmark where a special tax is levied on wage costs in the financial sector. The project for a similar tax in Sweden was strongly resisted by the financial sector and abandoned in 2017. Iceland and Norway have introduced a tax on wage costs and profits in 2012 and 2017 respectively.

Figure 12. VAT rates are high but efficiency slightly below average

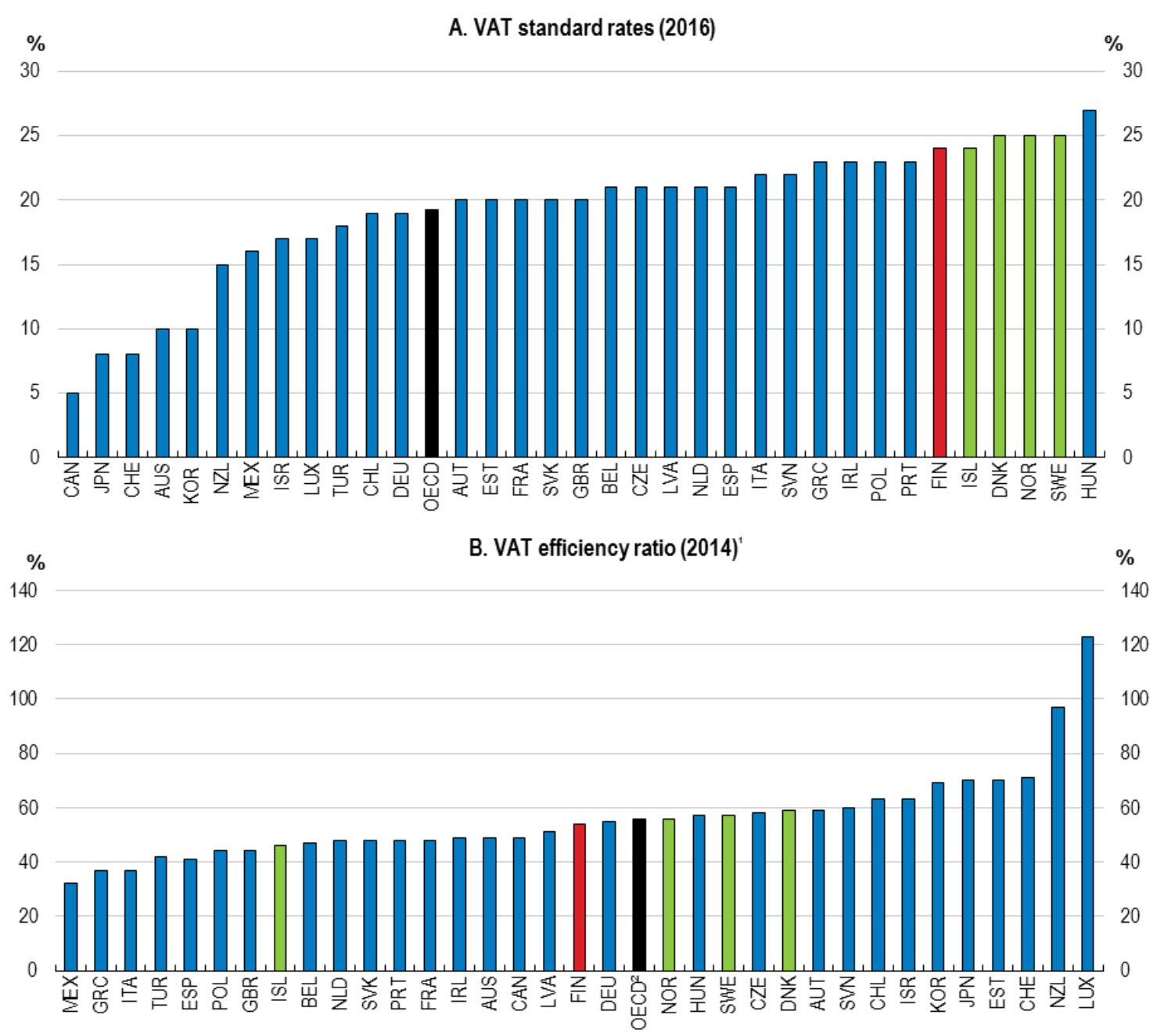

1. Ratio of actual VAT revenue to potential VAT revenue if all goods and services where taxed at the standard VAT rate.

2. OECD average excludes the United States.

Source: OECD (2016), Consumption Tax Trends 2016: VAT/GST and excise rates, trends and policy issues, OECD Publishing, Paris. 
The relatively low efficiency of Finnish VAT is mainly related to exemptions and reduced rates, as compliance is high (Thackray et al., 2015; CASE, 2016). Reduced VAT rates cost about EUR 2 billion (1\% of GDP) in 2014 in forgone tax revenue (Economic Policy Council, 2014). In most cases, reduced rates are justified by social and equity objectives. However, access to specific goods and services, such as food or cultural items for low-income households can generally be obtained more efficiently through targeted measures than through reduced VAT rates, which benefit all consumers and therefore imply large deadweight costs. Furthermore, having several VAT rates generates administrative and compliance costs.

Another argument often used to justify reduced VAT rates is to support labour-intensive economic activities, in particular restaurants. Reducing informality in these sectors may be a further motivation. However, the efficiency of such policies is questionable. The 2010 cut in the VAT rate for restaurants from $22 \%$ to $13 \%$ in Finland is estimated to have resulted in limited pass-through to prices and no significant impact on restaurants turnover and wage bill (Harju and Kosonen, 2013). Similar results were found with respect to the 2007 cut in VAT rates on hairdressing services from 22\% to 8\% (Kosonen, 2015). These findings are also broadly consistent with international experience. In Sweden, the 2012 cut in the VAT rate on restaurants and catering services from $25 \%$ to $12 \%$ is estimated to have had a modest positive impact on employment in the sector (Falkenhall, 2015; NIER, 2015). However, the impact on economy-wide employment is estimated to be very small and given the revenue foregone through the rate cut, its efficiency is questionable. The 2009 cut in the VAT rate on restaurants in France from 19.6\% to 5.5\% is estimated to have raised employment in the sector somewhat, but the cost per new job is very high compared to other policy measures. Furthermore, as high-income households tend to spend more on restaurants than low-income ones, the VAT cut is regressive (Conseil des Prélèvements Obligatoires, 2015).

Altogether, reduced VAT rates decrease government revenue significantly and in most cases their policy objectives could be achieved at a lower cost using targeted instruments. In addition, they reduce welfare by distorting spending decisions, as they modify relative prices. This calls for narrowing the number of goods and services subject to reduced rates. Nevertheless, this is likely to have distributional consequences, especially hurting low-income households. Changes to other taxes and benefits can offset the increase in inequality generated by harmonising VAT rates.

\section{Business taxation is aligned with other countries in the region}

At 20\%, the Finnish corporate income tax (CIT) rate is relatively low by OECD standards and close to those of the other Nordic countries (Figure 13, Panel A). Corporate tax revenue, as a share of GDP is also fairly low by OECD standards (Panel B). Competitive business taxation helps attract investment, but other factors like proximity to markets, good infrastructure, labour force skills and interdependence of activities within value chains are at least equally important in location decisions (Ketokivi et al., 2017). High marginal corporate tax rates are linked with significantly lower long-term output level (Akgun et al., 2017) and increase incentives for tax avoidance, as multinational companies can often shift profits from high to low-tax jurisdictions. Finnish business taxation is currently competitive, but corporate tax rate are being cut in neighbouring countries. Sweden is contemplating a cut in its corporate income tax rate from $22 \%$ to $20 \%$ taking effect in mid-2018, whose impact will, however, be mitigated by tighter limitations on interest deductibility. Denmark, while retaining a $22 \%$ CIT rate, will introduce an allowance for corporate equity and additional allowances for R\&D investment and SMEs in 2019. Norway is gradually reducing its CIT rate, which nevertheless remains higher than in Finland. The Estonian government has announced its intention to reduce the CIT rate, which only affects distributed profits, from $20 \%$ to $14 \%$. More generally, the global trend is towards lower CIT rates, with 15 OECD countries having implemented or announced CIT rate cuts since 2016 (OECD, 2017a). 
Figure 13. Corporate tax rate and revenue are low

A. Corporate tax rates (2017)

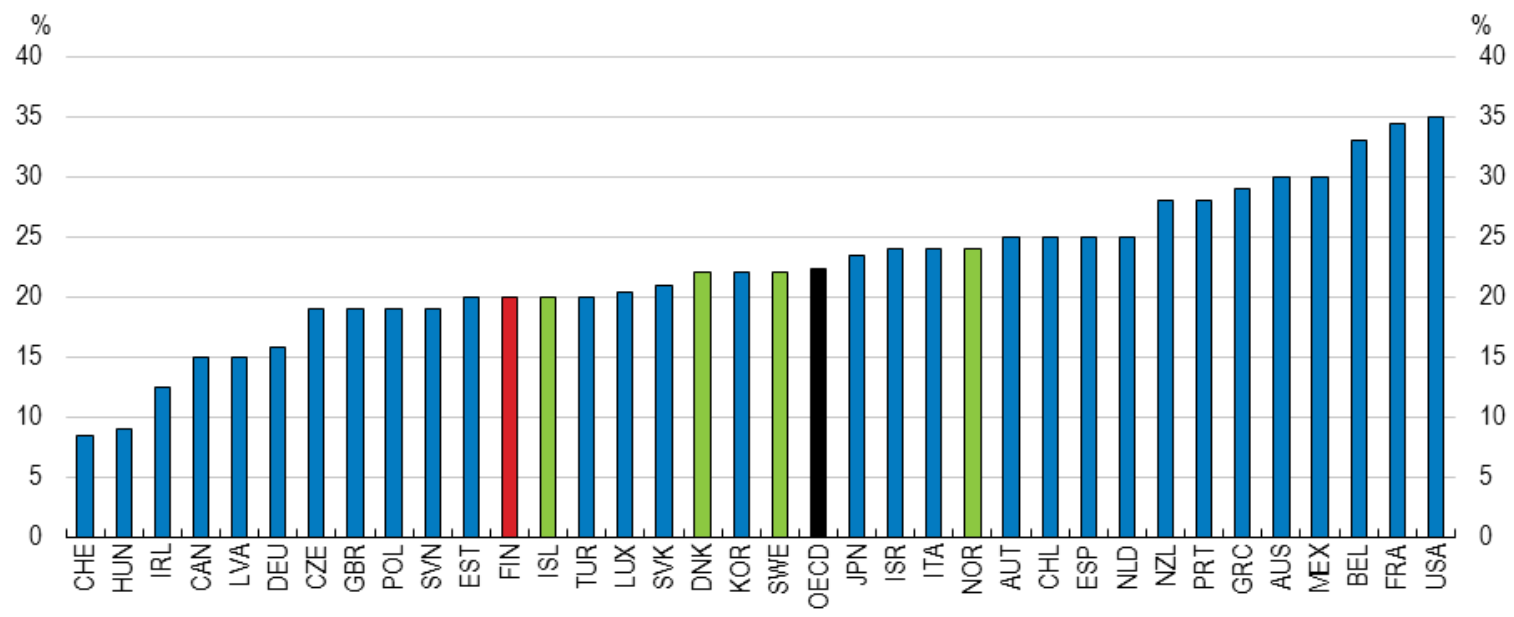

B. Corporate tax revenue (2012-2016) ${ }^{1}$

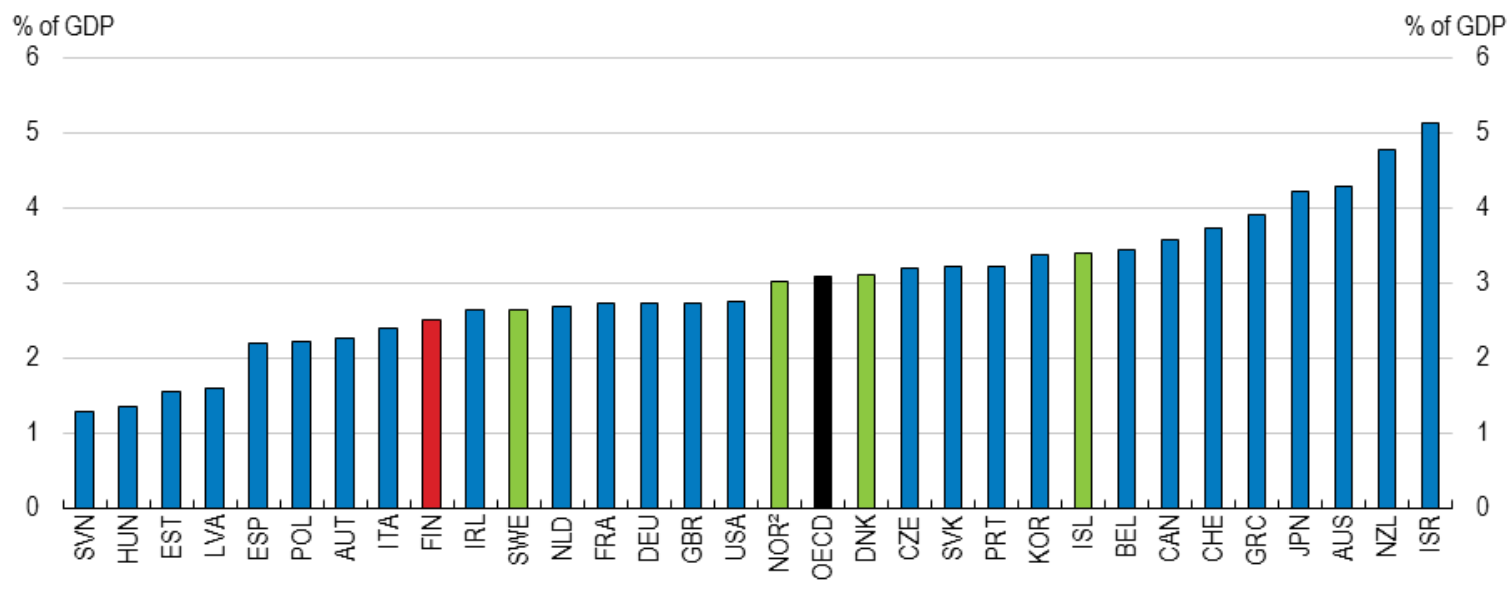

1. A five-year average is shown to account for the volatility of corporate tax revenue.

2. Mainland Norway.

Source: OECD Taxation database.

The successive cuts in corporate tax rates across Nordic countries look like a race to the bottom (Figure 14, Panel A). However, as such cuts are generally accompanied by base broadening and as the profit share in the economy has risen in most OECD countries, CIT revenue has not fallen proportionally to the statutory rate (Figure 14, Panel B). This is in line with broader international experience, where most countries which lowered their CIT rates significantly were able to offset the revenue loss through base broadening, raising other tax revenue or dynamic effects associated with the tax rate cut. Nevertheless, the opportunity to compensate rate cuts by tax-base broadening may be reaching its limits and dynamic effects are uncertain. 
Figure 14. Corporate tax revenue has so far held up relatively well despite sharp tax rate cuts

\section{A. Corporate tax rates}
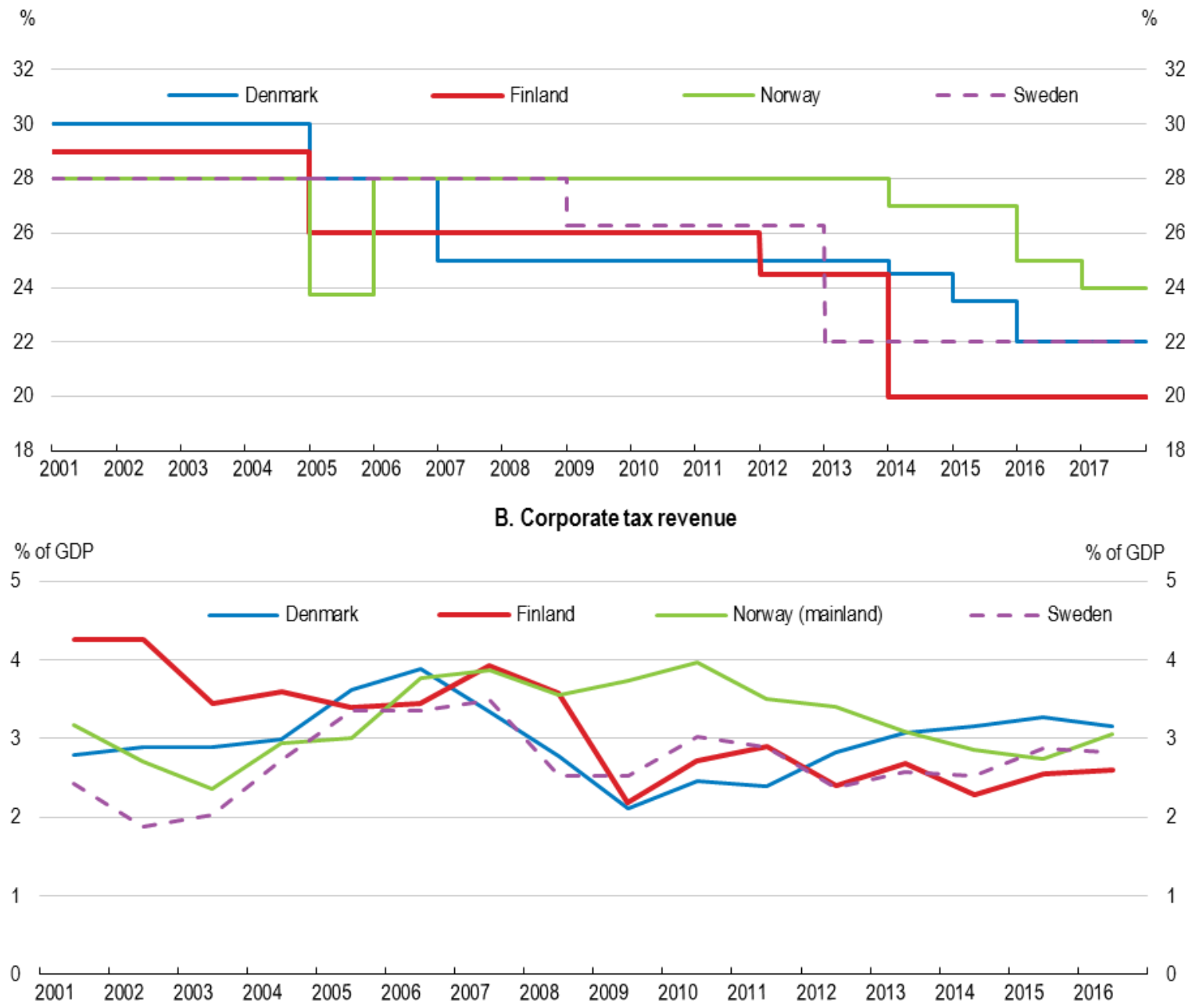

Source: OECD Taxation database.

In a global economy, protecting the tax base from erosion is a major challenge. Together with 70 other jurisdictions, Finland has signed the multilateral instrument (MLI) in June 2017. The MLI covers treaty-related minimum standards that were agreed as part of the Base Erosion and Profit Shifting (BEPS) package. These standards relate to the prevention of treaty abuse (Action 6) and the improvement of dispute resolution (Action 14). Furthermore, the MLI enables the parties to implement other tax treaty measures developed in the BEPS project, e.g. mandatory binding arbitration, or measures against artificial avoidance of permanent establishment status through commissionaire arrangements. Currently, Finland has chosen 71 tax treaties to be amended through the MLI, and opted for certain reservations. Finland is one of the 25 countries that have signed up for the multilateral arbitration mechanism, but has done so lodging some reservations. The MLI will allow Finland to transpose BEPS recommendations directly into its existing network of tax treaties; it will thus reinforce the anti-avoidance arsenal which is already part of Finnish tax legislation and includes controlled foreign company rules to limit tax avoidance through the use of affiliates in low-tax jurisdictions, transfer pricing rules which follow OECD guidelines and interest deduction limitations which prevent profit shifting through debt financing. The restriction on intra-firm interest deductibility imposed in 2014 is estimated to have lowered the financial expenses of Finnish multinational companies by $25 \%$ to $30 \%$, without noticeable effects on other profit shifting measures or real output (Harju et al., 2017). 


\section{Box 1. Tackling tax avoidance: The OECD/G20 BEPS project}

Base erosion and profit shifting (BEPS) refers to tax planning strategies of multinational enterprises (MNEs) that exploit gaps in tax rules to artificially shift profits to low- or no-tax locations where they have little or no economic activity. BEPS poses a serious risk to government tax revenue. It is estimated that between $4 \%$ and $10 \%$ of global corporate income tax revenue, i.e. USD 100 to 240 billion annually, is being lost due to BEPS (OECD, 2015a). In addition to tax revenue losses, BEPS has other adverse economic effects, including exacerbating the corporate debt bias and misdirecting foreign direct investment. It also undermines competition by giving an unfair advantage to taxaggressive MNEs relative to domestic enterprises whose opportunities for tax planning are more limited. The OECD/G20 BEPS project produced a 15-point Action Plan including minimum standards, common approaches, best practices and new guidance in the main policy areas.

- Minimum standards have been agreed upon in the areas of fighting harmful tax practices (Action 5), preventing treaty abuse (Action 6), country-by-country reporting (Action 13) and improving dispute resolution (Action 14). All participating countries are expected to implement these minimum standards and implementation will be subject to peer review.

- A common approach, which will facilitate the convergence of national practices by interested countries, has been outlined to limit base erosion through interest expenses (Action 4) and to neutralise hybrid mismatches (Action 2). Best practices for countries which seek to strengthen their domestic legislation are provided on the building blocks for effective controlled foreign company (CFC) rules (Action 3 ) and mandatory disclosure by taxpayers of aggressive or abusive transactions, arrangements or structures (Action 12).

- $\quad$ The permanent establishment (PE) definition in the OECD Model Tax Convention has been changed to restrict inappropriate avoidance of tax nexus through commissionaire arrangements or exploitation of specific exceptions (Action 7). Follow-up work is being undertaken which will also provide further guidance on the attribution of profits to PEs. In terms of transfer pricing, important clarifications have been made with regard to delineating the actual transaction, and the treatment of risk and intangibles. More guidance has been provided on several other issues to ensure that transfer pricing outcomes are aligned with value creation (Actions 8-10).

- $\quad$ The changes to the PE definition, the clarifications on transfer pricing, and the guidance on CFC rules are expected to substantially address the BEPS risks exacerbated by the digital economy. Several other options, including a new nexus in the form of a significant economic presence, were considered, but not recommended at this stage given the other recommendations plus Value Added Taxes (VAT) will now be levied effectively in the destination- country facilitating VAT collection (Action 1).

- $\quad$ The Multilateral Convention to Implement Tax Treaty Related Measures to Prevent BEPS (the Multilateral Instrument or MLI) has been signed in June 2017 to facilitate the modification of bilateral tax treaties (Action 15). The modifications made to existing treaties will address the minimum standards against treaty abuse as well as the updated PE definition.

At the February 2016 G20 Finance Ministers meeting, the Inclusive Framework for the global implementation of the BEPS project was endorsed, with a reiteration of the commitment to timely implementation of the BEPS project and to continue monitoring and addressing BEPS-related issues for a consistent global approach.

Monitoring the implementation and impact of the different BEPS measures is a key element of the work of the Inclusive Framework. Members of the Inclusive Framework are developing a monitoring process for the four BEPS minimum standards as well as put in place the review mechanisms for other elements of the BEPS package. In June 2017, 102 countries have become a member of the Inclusive Framework on BEPS.

For more information: http://www.oecd.org/tax/beps/inclusive-framework-on-BEPS-progress-report-july-2016june-2017.pdf.

The taxation of unlisted corporations involves different challenges. While the main rationale for source-based taxation of big corporations is to tax location-specific economic rents, taxation of smaller companies is more about protecting the personal income tax base (Mirrlees et al., 2011). Like most other Nordic countries, Finland has a dual income tax system (DIT), where capital income is taxed at a flat rate (although a slightly higher rate applies beyond a certain threshold), while revenue from labour and transfers is taxed at a progressive rate schedule. The system was put in place in 1993, mainly to reduce the risk of capital flight. A drawback of this system is that it creates incentives for reclassifying labour income as capital income, where the earnings of owners are a combination of both types of income. Indeed, 
analyses of the impact of the tax reforms of 1993 and 2005, which modified the relative taxation of labour and capital, find evidence of income reclassification (Pirttilä and Selin, 2011; Harju and Matikka, 2015). Reclassification of income from labour to capital can be addressed through anti-avoidance legislation, but this addresses the symptoms rather than the causes and can vastly increase complexity, generating important compliance and administrative costs. Aligning taxation of labour and capital is arguably a better option.

Norway introduced a rate of return allowance (RRA) in its personal income tax in 2006. Dividends and realised capital gains below a notional return are exempt from personal income tax, as profits have already been taxed at the corporate level. Capital income in excess of the RRA is subject to personal income tax. The overall tax rate on capital income, accounting for both corporate and dividend taxation, is close to the top marginal labour income tax rate (including statutory personal income tax and employee and employer maximum social security contributions), which reduces income reclassification opportunities. The RRA system displays a number of attractive properties. In particular, it is neutral with respect to the marginal cost of investment and treats dividends and retained earnings symmetrically, avoiding lock-in effects hampering the reallocation of capital. The remaining distortion due to taxation on realised income is mitigated by the possibility to carry the RRA forward (Sørensen, 2010).

The introduction of the RRA has also contributed to increase income redistribution by removing opportunities to lower taxes through income reclassification (Norwegian Ministry of Finance, 2011). However, the RRA does not generate neutrality between debt and equity financing at the corporate level for non-resident investors in an open economy, as distortions are only removed for domestic investors. Similarly, the cost of capital for large firms is unlikely to be reduced, as it essentially depends on required returns at the global level. Nevertheless, the cost of capital may be reduced for smaller companies, which are not fully integrated in the global financial market, although views on the issue differ (Lindhe and Södersten, 2012; Sørensen, 2014). Adopting a RRA system in Finland would reduce distortions to investment and financing, but similar neutrality properties may be obtained by modifying some tax parameters of the current system, notably the normal rate of return (Kari and Ropponen, 2016).

In Finland, for dividend income above EUR 150000 and below 8\% of the value of the shares owned, $15 \%$ of dividend income is exempt from capital income tax. For a return above $8 \%$ of the value of the shares owned, $75 \%$ of the dividend income is taxed as earned income and the remaining $25 \%$ is taxexempt. In principle, there is no reason to exempt dividends beyond a risk-free return, provided the tax treatment of profits and losses is symmetric (Mirrlees, 2011), which to a large extent is the case in Finland (Hanappi, 2016). The 10-year limit on loss carry-forward and a restriction to deductions from the same category of revenue (business, agricultural or personal income) seem to be binding only in a limited number of cases. Hence, with a rate of return of $8 \%$ used to determine dividend tax relief and current government bond yields well below $1 \%$, the risk premium looks excessive. It encourages accumulation of capital in unlisted companies, which may result in sub-optimal allocation of capital across the economy.

The expert group on business taxation appointed by the Ministry of Finance proposed a number of changes to enhance neutrality between investments in businesses of different legal forms. In particular, it recommended reducing the maximum rate of return used for determining the share of the dividends eligible for tax relief to $4 \%$ and lifting some restrictions on loss deductions (Ministry of Finance, 2017b). The recommended rate of $4 \%$ could be seen as a nominal risk-free rate, insofar as it is roughly equivalent to the long-term average real government bond rate augmented by the current inflation target of $2 \%$. Hence, the expert groups' recommendations seem reasonable, even though defining the normal rate as a spread over the government bond yield, may be preferable in order to allow automatic adjustments in the future. 


\section{Encouraging greener growth}

Finland has ambitious climate change and environmental policy objectives, in line with its commitment under the Paris Climate Agreement and the EU 2030 energy policy targets. The objectives include lifting the share of renewable energy to $50 \%$ of final consumption, phasing out coal use, halving the domestic use of imported oil and raising the share of renewable transport fuels to $40 \%$ by 2030 . A further objective is to lower greenhouse gas emissions by at least $80 \%$ relative to the 1990 level by 2050 (Ministry of Economic Affairs and Employment, 2017). The tax system, along with other instruments like the EU Emissions Trading System (ETS), regulations and R\&D, has a key role to play in achieving these objectives. The distributional effects of energy taxes are mixed. Taxes on transport fuels tend to make up a smaller share of total pre-tax expenditure for the poorest households, in Finland as in most OECD countries. Conversely, taxes on heating fuels and electricity weigh more on the poorest, although they amount for a small share of their consumption (respectively $0.4 \%$ and $0.7 \%$ for heating fuels and electricity in the lowest consumption decile, versus $1 \%$ for transport fuels). Besides, energy taxes impose a heavier burden on households in rural areas than on urban dwellers, which use less transport fuels (Flues and Thomas, 2015). Overall, the risk of adverse distributional impacts of increasing energy taxation looks relatively modest.

Revenues from taxes on energy use have increased gradually and when measured as a percentage of GDP they are high by OECD standards (Figure 15). However, tax rates vary across energy uses - e.g. heating and process use, power production or transport - and sectors - e.g. energy producers, manufacturing industry or households. A number of industries or fuels benefit from reduced tax rates (OECD, 2013) or direct refunds. A few years ago, a working group led by the Ministry of Finance identified between EUR 2.7 and EUR 4.5 billion in production-linked reduced rates and direct subsidies which can heighten environmental pressures, mainly in energy, transport and agriculture (Hyyrynen, 2013). In particular, the following reduce the effectiveness of energy taxation:

- Energy-intensive industries paying more than $0.5 \%$ of their annual value added in fuel and electricity tax are entitled to a tax refund of $85 \%$ of the amount paid above that threshold. The refund only applies to the share exceeding EUR 50000.

- Tax rates are lower on diesel than on gasoline, as in most OECD countries (Figure 16), although combusting diesel emits higher levels of carbon dioxide per litre than gasoline and, depending on the emission control technology employed, often also more harmful air pollutants. This gap is partly (yet not very effectively) offset by a higher annual tax on diesel vehicles, but diesel remains advantageous for intensive users, despite a higher environmental cost per kilometre for diesel than for petrol vehicles (Harding, 2014). Furthermore, raising diesel taxation to the level applied on gasoline would spur the development of alternative fuels and transport modes (Bragadóttir et al., 2014).

- Taxation of peat, which generates high $\mathrm{CO}_{2}$ emissions and air pollution, is low due to its technical qualities in combined heat and power production, energy security, widespread availability, price stability and contribution to regional economic development (IEA, 2013). The energy tax on peat was re-introduced in 2011, but at a much lower level than for other fuels (OECD, 2013).

- Agriculture benefits both from direct subsidies for activities with a potentially harmful impact on the environment and from subsidies on fuels. Intensive agriculture can have a negative impact on the environment through greenhouse gas emissions and through nutrient leaching, which causes eutrophication of rivers, lakes and seas.

- Over-allocation of EU Emission Trading System (ETS) permits can be considered as an environmentally harmful subsidy, as it lowers the average price of emitting $\mathrm{CO}_{2}$ for ETS sectors below its social cost. The low carbon price resulting from the surplus of trading permits following the global economic slowdown has encouraged the use of more $\mathrm{CO}_{2}$-intensive energy sources (Bragadóttir et al., 2014). In addition, the free allocation of permits can create windfall 
profits for carbon-intensive industries and can skew investment decisions towards carbonintensive technologies. Full auctioning of tradable permits avoids these drawbacks (OECD, 2017c).

Figure 15. Environmentally related tax revenue is high compared to other OECD countries 2015 or latest

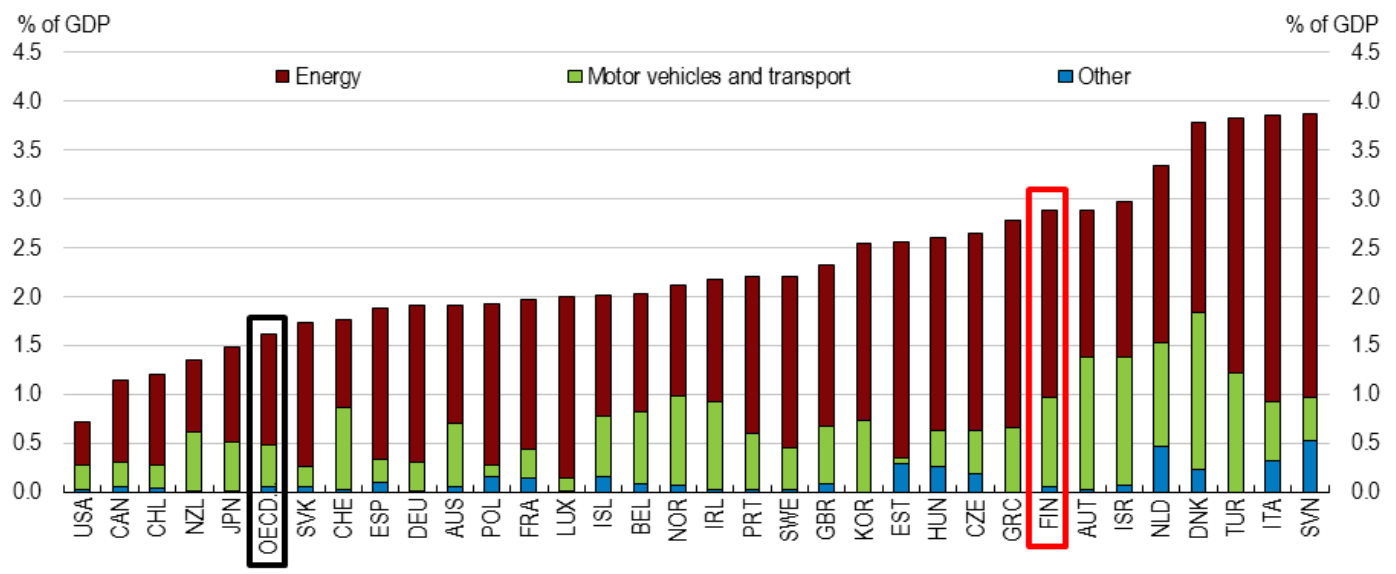

Source: OECD Instruments Used for Environmental Policy database.

Figure 16. Diesel is lightly taxed compared to gasoline

Effective tax rates on gasoline and diesel for road use

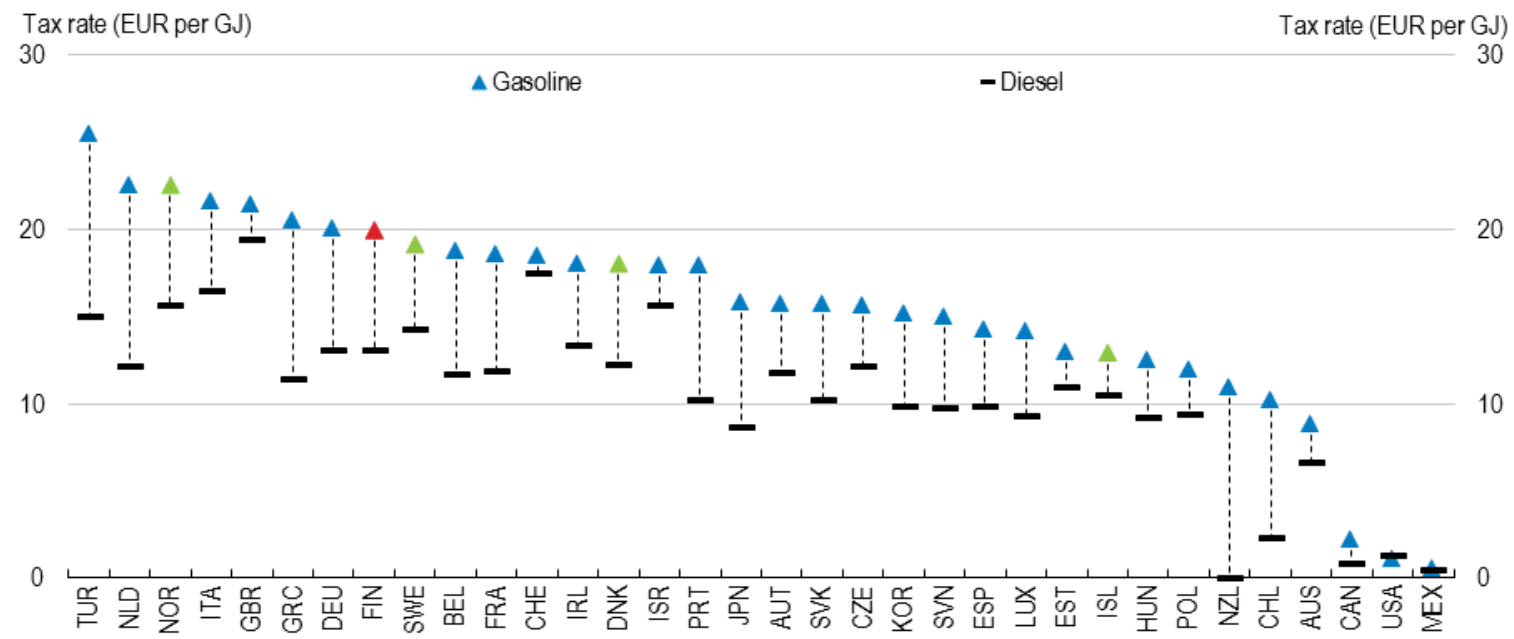

Source: OECD (2015c), Taxing Energy Use 2015: OECD and Selected Partner Economies, OECD Publishing, Paris.

Increasing environmentally-related taxes and reducing or removing environmentally harmful subsidies is a challenging task, as this often raises concerns relating to the competitiveness of firms and industries and the income distribution of households. A number of measures have been taken in recent years, including increases in some energy, $\mathrm{CO}_{2}$ and vehicle taxes, the removal of the tax exemption on liquefied petroleum gas and reductions on allowances to deduct commuting expenses. Although further progress is necessary to reach the climate change and environmental policy objectives at a low cost for society and to reflect the environmental damage of energy use in prices, advances will require taking into consideration wider socio-economic and competitiveness effects. However, competitiveness and equity objectives, where relevant, are typically better addressed by flanking measures than by adjusting the rates or coverage of environmentally related taxes (OECD, 2017d). 


\section{REFERENCES}

Adema, W., P. Fron and M. Ladaique (2011), "Is the European welfare State really more expensive? Indicators on social spending, 1980-2012; and a Manual to the OECD Social Expenditure Database (SOCX)", OECD Social, Employment and Migration Working Papers, No. 124, OECD Publishing, Paris. http://dx.doi.org/10.1787/5kg2d2d4pbf0-en

Akgun, O., B. Cournède and J. Fournier (2017), "The effects of the tax mix on inequality and growth", OECD Economics Department Working Papers, No. 1447, OECD Publishing, Paris. http://dx.doi.org/10.1787/c57eaa14-en

Andersen, T.M. et al. (2007), The Nordic Model. Embracing Globalization and Sharing Risks, The Research Institute of the Finnish Economy (ETLA), Taloustieto Oy, Helsinki.

Andersen, T.M. and A. Sørensen (2014), "Taxation - Financing the welfare state in a more globalized world", in: Valkonen, T. and V. Vihriälä (eds.), The Nordic Model - Challenged but Capable of Reform, Nordic Council of Ministers, Copenhagen.

Arnold, J. M., B. Brys, C. Heady, Å. Johansson, C. Schwellnus and L. Vartia (2011), "Tax policy for economic recovery and growth", The Economic Journal, 121.

Barr, N. (2004), "Higher Education Funding”, Oxford Review of Economic Policy, Vol. 20, No. 2.

Barr, N. et al. (2017), "Getting student financing right in the US: lessons from Australia and England", Working Paper No. 16, Centre for Global Higher Education, London.

Belfield, C. et al. (2017), "Higher Education funding in England: past, present and options for the future", IFS Briefing Note BN211, The Institute for Fiscal Studies, London.

Bird, R.M. (2001), "User Charges in Local Government Finance”, in R. Stren and M.E. Freire, eds., The Challenge of Urban Government, World Bank Institute, Washington D.C.

Blöchliger, H. et al. (2015a), "The stabilisation properties of immovable property taxation: Evidence from OECD countries", OECD Economics Department Working Papers, No. 1237, OECD Publishing, Paris. http://dx.doi.org/10.1787/5js0cqq93djg-en

Blöchliger, H. (2015b), "Reforming the tax on immovable property: taking care of the unloved", $O E C D$ Economics Department Working Papers, No. 1205, OECD Publishing, Paris. http://dx.doi.org/10.1787/5js30tw0n7kg-en

Botev, J., J. Fournier and A. Mourougane (2016), "A reassessment of fiscal space in OECD countries", OECD Economics Department Working Papers, No. 1352, OECD Publishing, Paris. http://dx.doi.org/10.1787/fec60e1b-en

Bragadóttir, H. et al. (2014), The Use of Economic Instruments in Nordic Environmental Policy 20102013, TemaNord 2014:549, Nordic Council of Ministers, Copenhagen.

CASE (2016), Study and Reports on the VAT Gap in the EU-28 Member States: 2016 Final Report, Center for Social and Economic Research, Warsaw.

Conseil des Prélèvements Obligatoires (2015), La taxe sur la valeur ajoutée, Paris. 
Falkenhall, B., S. Tano and J. Månsson (2015), "Impact of the VAT reform on Swedish restaurants - a synthetic control group approach", PM 2015:25, Swedish Agency for Growth Policy Analysis, Östersund.

Finnish Economic Policy Council (2015), Economic Policy Council Report 2014, Economic Policy Council, VATT Institute for Economic Research, Helsinki.

Flues, F. and A. Thomas (2015), "The distributional effects of energy taxes", OECD Taxation Working Papers, No. 23, OECD Publishing, Paris. http://dx.doi.org/10.1787/5js1qwkqqrbv-en

Flues, F. and K. Van Dender (2017), "The impact of energy taxes on the affordability of domestic energy", OECD Taxation Working Papers, No. 30, OECD Publishing, Paris. http://dx.doi.org/10.1787/08705547-en

Fournier, J. and $\AA$. Johansson (2016), "The effect of the size and the mix of public spending on growth and inequality", OECD Economics Department Working Papers, No. 1344, OECD Publishing, Paris. http://dx.doi.org/10.1787/f99f6b36-en

Hanappi, T. (2016), "Loss carryover provisions: measuring effects on tax symmetry and automatic stabilisation", CTPA/CFA/WP2/NOE2(2016)25/REV1.

Harding, M. (2014), "The diesel differential: differences in the tax treatment of gasoline and diesel for road use", OECD Taxation Working Papers, No. 21, OECD Publishing, Paris. http://dx.doi.org/10.1787/5jz14cd7hk6b-en

Harju, J. and T. Kosonen (2013), “Restaurant VAT cut: cheaper meal and more service?", VATT Working Papers, No. 52, Government Institute for Economic Research, Helsinki.

Harju, J. and T. Matikka (2015), "Business owners and income-shifting: evidence from Finland", Small Business Economics, No. 46.

Harju, J., I. Kauppinen and O. Ropponen (2017), "Firm responses to an interest barrier: empirical evidence", VATT Working Papers, No. 90, Government Institute for Economic Research, Helsinki.

Hyyrynen, M. (2013), Environmentally Harmful Subsidies, Reports of the Ministry of the Environment, 13/2013, Ministry of the Environment, Helsinki (in Finnish).

IEA (2013), Energy Policies of IEA Countries: Finland 2013, International Energy Agency, Paris.

Johansson, Å. (2016), "Public finance, economic growth and inequality: A survey of the evidence", OECD Economics Department Working Papers, No. 1346, OECD Publishing, Paris. http://dx.doi.org/10.1787/094bdaa5-en

Kari, S. and O. Ropponen (2016), "A note on the effects of income-splitting under dual income tax", VATT Working Papers, No. 81, Government Institute for Economic Research, Helsinki.

Ketokivi, M. et al. (2017), "Why locate manufacturing in a high-cost country? A case study of 35 production location decisions", Journal of Operations Management, 49-51.

Kosonen, T. (2015), "More and cheaper haircuts after VAT cut? On the efficiency and incidence of service sector consumption taxes", Journal of Public Economics, Vol. 131. 
Koutsogeorgopoulou, V. (2016), "Addressing the challenges in higher education in Norway", OECD Economics Department Working Papers, No. 1285, OECD Publishing, Paris. http://dx.doi.org/10.1787/5jm0xf28vw8s-en

Lehmus, M. (2014), "Distributional and employment effects of labour tax changes in Finland", Journal of Policy Modeling, Vol. 36.

Lindhe, T. and J. Södersten (2012), “The Norwegian shareholder tax reconsidered", International Tax and Public Finance, Vol. 19, Issue 3.

Määttänen, N. and V. Vihriälä (2017), "Kolme keinoa turvata tutkimuksen ja koulutuksen rahoitus", Research Institute of the Finnish Economy (ETLA) Muistio, No. 58, Helsinki.

Ministry of Economic Affairs and Employment (2017), Government report on the National Energy and Climate Strategy for 2030, Publications of the Ministry of Economic Affairs and Employment 12/2017, Helsinki.

Ministry of Finance (2017a), Outlook and Challenges for Finland's Public Finances, Ministry of Finance publications 7b/2017, Helsinki.

Ministry of Finance (2017b), "Yritysverotuksen asiantuntijatyöryhmän raportti”, Ministry of Finance publications 12/2017, Helsinki.

Mirrlees et al. (2011), Tax by Design: The Mirrlees Review, Oxford University Press.

Moisio, P., K.-M. Lehtelä and S. Mukkila (2016), "Poverty reduction effects of taxation and benefit policies in Finland, 1993-2013", European Journal of Social Security, Vol. 18, No. 1.

Muellbauer, J. (2006), "Housing and personal wealth in a global context", paper prepared for the United Nations-WIDER Project Meeting, "Personal Assets from a Global Perspective", Helsinki, Finland, 4-6 May.

NIER (2015), "Kort- och långsiktiga effekter av sänkt restaurangmoms”, Specialstudier Nr. 46, National Institute of Economic Research, Stockholm.

Norwegian Ministry of Finance (2011), Evaluation of the 2006 Tax Reform, Report No. 11 (white paper) to the Storting (2010-2011), Norwegian Government, Oslo.

OECD (2012), "How are countries around the world supporting students in higher education?", Education Indicators in Focus, No. 2012/02, OECD Publishing, Paris.

OECD (2013), Taxing Energy Use: A Graphical Analysis, OECD Publishing, Paris. DOI: http://dx.doi.org/10.1787/9789264183933-en.

OECD (2015a), Measuring and Monitoring BEPS, Action 11 - 2015 Final Report, OECD/G20 Base Erosion and Profit Shifting Project, OECD Publishing, Paris. http://dx.doi.org/10.1787/9789264241343-en

OECD (2015b), Taxation of SMEs in OECD and G20 Countries, OECD Tax Policy Studies, No. 23, OECD Publishing, Paris. http://dx.doi.org/10.1787/9789264243507-en 
OECD (2015c), Taxing Energy Use: OECD and selected Partner economies, OECD Publishing, Paris, DOI: http://dx.doi.org/10.1787/9789264232334-en.

OECD (2016a), Education at a Glance 2016: OECD Indicators, OECD Publishing, Paris. http://dx.doi.org/10.187/eag-2016-en

OECD (2016b), OECD Economic Surveys: Finland 2016, OECD Publishing, Paris. http://dx.doi.org/10.1787/eco_surveys-fin-2016-en

OECD (2016c), Consumption Tax Trends 2016: VAT/GST and Excise Rates, Trends and Policy Issues, OECD Publishing, Paris. http://dx.doi.org/10.1787/cct-2016-en

OECD (2016d), Back to Work: Finland: Improving the Re-employment Prospects of Displaced Workers, OECD Publishing, Paris. http://dx.doi.org/10.1787/9789264264717-en

OECD (2017a), Tax Policy Reforms 2017: OECD and Selected Partner Economies, OECD Publishing, Paris. http://dx.doi.org/10.1787/9789264279919-en.

OECD (2017b), Taxation and Skills, OECD Tax Policy Studies, No. 24, OECD Publishing, Paris. http://dx.doi.org/10.1787/9789264269385-en.

OECD (2017c), Investing in Climate, Investing in Growth, OECD Publishing, Paris. DOI: http://dx.doi.org/10.1787/9789264273528-en.

OECD (2017d), Environmental Fiscal Reform. Progress, prospects and pitfalls. OECD Report for the G7 Environment Ministers, https://www.oecd.org/tax/tax-policy/environmental-fiscal-reform-G7environment-ministerial-meeting-june-2017.pdf

Pareliussen, J.K. and H. Hwang (2018), "Benefit reform for employment and equal opportunity in Finland", OECD Economics Department Working Papers, No. 1467, OECD Publishing, Paris.

Pirttilä, J. and H. Selin (2011), "Income shifting within a dual income tax system: evidence from the Finnish tax reform of 1993”, Scandinavian Journal of Economics, Vol. 113, No. 1.

Prime Minister's Office (2015), Finland, a Land of Solutions, Strategic Programme of Prime Minister Juha Sipilä's Government, Government Publications 12/2015, Helsinki.

Riihelä, M. et al. (2002), "Recent trends in income inequality in Finland", Labour Institute for Economic Research Discussion Papers, No. 183, Helsinki.

Riihelä, M., R. Sullström and I. Suoniemi (2008), “Tax progressivity and recent evolution of the Finnish income inequality”, Labour Institute for Economic Research Discussion Papers, No. 246, Helsinki.

Sørensen, P.B. (2010), "Dual income taxes: a Nordic tax system”, in: I. Claus et al. (eds.), Tax Reform in Open Economies, Edward Elgar.

Thackray, M., E. Hutton, and K. Kapoor (2015), Finland, Revenue Administration Gap Analysis Program, The Value-Added Tax Gap, International Monetary Fund, Washington D.C.

Van den Noord, P. (2005), "Tax incentives and house prices in the euro area: theory and evidence", Economie Internationale, No. 101. 